Article

\title{
Automated Coastline Extraction Using the Very High Resolution WorldView (WV) Satellite Imagery and Developed Coastline Extraction Tool (CET)
}

\author{
Fran Domazetović ${ }^{1, *(D)}$, Ante Šiljeg ${ }^{1}$ (D) Ivan Marić ${ }^{1}\left(\mathbb{D}\right.$, Josip Faričić $^{1}\left(\mathbb{D}\right.$, Emmanuel Vassilakis ${ }^{2}$ (D) \\ and Lovre Panđa ${ }^{1}$
}

1 Department of Geography, University of Zadar, 23000 Zadar, Croatia; asiljeg@unizd.hr (A.Š.); imaric1@unizd.hr (I.M.); jfaricic@unizd.hr (J.F.); lpanda@unizd.hr (L.P.)

2 Faculty of Geology and Geoenvironment, National and Kapodistrian University of Athens, 15784 Athens, Greece; evasilak@geol.uoa.gr

* Correspondence: fdomazeto@unizd.hr; Tel.: +385-992-445-064

check for updates

Citation: Domazetović, F.; Šiljeg, A.; Marić, I.; Faričić, J.; Vassilakis, E.; Panđa, L. Automated Coastline Extraction Using the Very High Resolution WorldView (WV) Satellite Imagery and Developed Coastline Extraction Tool (CET). Appl. Sci. 2021, 11,9482. https://doi.org/10.3390/ app11209482

Academic Editor: Lorena Parra

Received: 20 September 2021

Accepted: 4 October 2021

Published: 12 October 2021

Publisher's Note: MDPI stays neutral with regard to jurisdictional claims in published maps and institutional affiliations.

Copyright: (c) 2021 by the authors. Licensee MDPI, Basel, Switzerland. This article is an open access article distributed under the terms and conditions of the Creative Commons Attribution (CC BY) license (https:// creativecommons.org/licenses/by/ $4.0 /)$.

\begin{abstract}
The accurate extraction of a coastline is necessary for various studies of coastal processes, as well as for the management and protection of coastal areas. Very high-resolution satellite imagery has great potential for coastline extraction; however, noises in spectral data can cause significant errors. Here, we present a newly developed Coastal Extraction Tool (CET) that overcomes such errors and allows accurate and time-efficient automated coastline extraction based on a combination of WorldView-2 (WV-2) multispectral imagery and stereo-pair-derived digital surface model (DSM). Coastline extraction is performed and tested on the Iž-Rava island group, situated within the Northern Dalmatian archipelago (Croatia). Extracted coastlines were compared to (a) coastlines extracted from state topographic map $(1: 25,000)$, and (b) coastline extracted by another available tool. The accuracy of the extracted coastline was validated with centimeter accuracy reference data acquired using a UAV system (Matrice 600 Pro + MicaSense RedEdge-MX). Within the study area, two small islets were detected that have not been mapped during the earlier coastline mapping efforts. CET proved to be a highly accurate coastline mapping technique that successfully overcomes spectral-induced errors. In future research, we are planning to integrate data obtained by UAVs infrared thermography (IRT) and in situ sensors, measuring sea and land surface temperatures (SST and LST), into the CET, given that this has shown promising results. Considering its accuracy and ease of use, we suggest that CET can be applied for automated coastline extraction in other large and indented coastal areas. Additionally, we suggest that CET could be applied in longitudinal geomorphological coastal erosion studies for the automated detection of spatio-temporal coastline displacement.
\end{abstract}

Keywords: coastline extraction tool (CET); WorldView; multispectral data; thermal imagery

\section{Introduction and Background}

Coastal zones represent oscillating, highly dynamic environments between the water surface and a certain land surface [1]. Today, coastal zones are economic and population hotspots, highly endangered by various anthropogenic pressures (e.g., excessive urbanization and construction, agricultural exploitation, pollution) [2,3] and natural or climate change-related processes (e.g., sea-level rise, storm surges, coastal erosion, tsunamis, salinization) [4-7]. Anthropogenic pressures are caused by the nearly 2.4 billion people (40\% of the total world's population) living within the $100 \mathrm{~km}$ from the coastline [8]. In this manuscript, the precise demarcation line between land and water is defined as a coastline. Sometimes, the term shoreline is also used, although there are minor differences between them [9-12]. In simple terms, the coastline is the boundary of the continent/island, while the shoreline is the boundary of the land [13]. The coastline term was used following these two reasons (1) this manuscript studies the Iž-Rava island group and (2) the term 
"coastline" is used within a large number of papers about automatic extraction of that demarcation line, published in the last couple of years [14-17]. The instantaneous coastline can be most easily defined as the physical interface of land and water (LWI) [18] at one instant in time [10] which are very hard to extract due to constant water level changes [19]. An alternative definition of coastline can be a particular elevation contour of the land (or water) surface [20]. Coastline changes are regarded as one of the most dynamic processes (a time-dependent phenomenon) in coastal zones [21,22] and critical information in the Coastal Geographic Information System (CGIS) [19]. The combination of these factors made a study of changing coastlines more than a topic of scientific curiosity [23]. Therefore, they are considered as one of the most important linear dynamic features on the Earth's surface [12].

Coastline mapping is crucial for detection and monitoring of various coastal spatiotemporal changes [24-26], the study of specific coast-related processes and pressures such as coastal erosion $[27,28]$, urbanization $[29,30]$, management and protection of endangered coastal areas [31-33], maritime affairs and safe navigation, sustainable coastal development and planning, and monitoring and protection of endangered coastal ecosystems [15,34-36]. Therefore, accurate coastline mapping is crucial not only from a scientific perspective but for its importance for society, as it can provide valuable information that can be essential in mitigating the above-mentioned problems and pressures [37,38]. However, accurate coastline mapping is not a simple task, especially over large, intended, and remote areas [39]. The complexity of coastline mapping can be best expressed by the "coastline paradox" (Figure 1), which means that coastline length depends on the research scale and accuracy of the used measurement method $[40,41]$. Less detailed research scale and less accurate measurement methods result in generalized coastline depiction, where the actual length of the coastline is reduced. At the same time, more detailed and accurate methods result in a more accurate representation of the actual coastline.

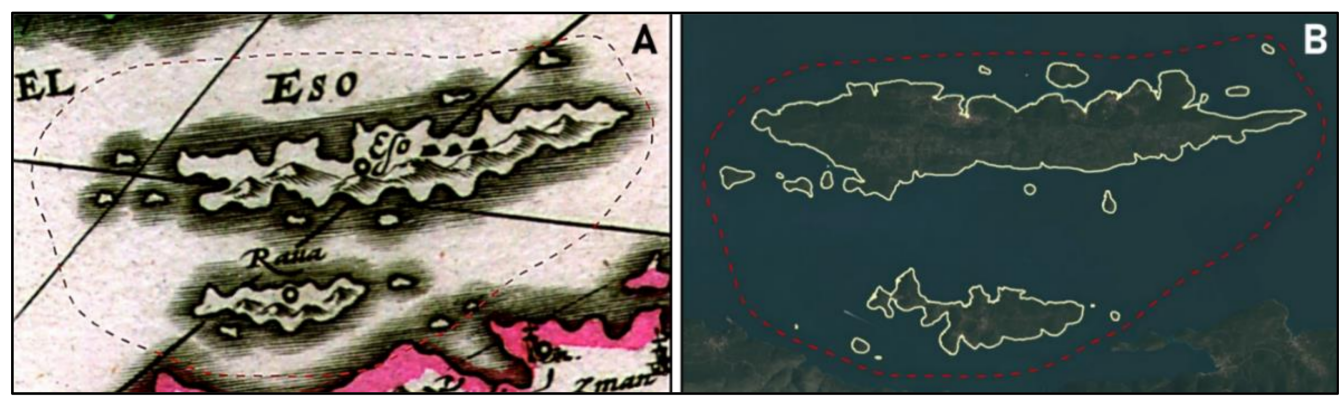

Figure 1. Coastal paradox demonstrated by the representation of Iž-Rava island group in Janszoon's Map of Northern Dalmatia, Amsterdam, c. 1620 [Jan Janszoon, Iadera sicum et Aenona vulgo Zara, Sebenico et Nona cum insulis adjacentibus in parte Dalmatiae boreali, Amsterdam, c. 1620 (National and University Library, Zagreb, Map and Atlas Collection, Novak Collection, Call number ZN-Z-XVIIJAN-1620b)] (A) and Worldview imagery, 2016 (B).

Many different methods for coastline extraction have been developed [19,24,42]. However, the accuracy and quality of coastline depictions were often inadequate due to the modest mapping capabilities, which were limited by earlier field data collection methods [24]. These traditional coastline mapping methods required labor-intensive and extensive mapping processes, which often resulted in generalized and inaccurate coastline representations [43]. With the emergence of different remote sensing techniques and very high resolution (VHR), satellite imagery new automatic and semi-automatic coastline extraction methods have been developed [14,15,22,23,44-46]. A detailed review of various existing automatic and semi-automatic coastline extraction methods, along with their main advantages and limitations, is given in Table 1 . Such methods have provided new momentum to the coastal mapping efforts, as they minimized required fieldwork activities and allowed semi-automated or automated mapping over large areas [47,48]. Furthermore, the high temporal resolution of such imagery has simplified the multi-temporal quantification 
of coastal changes [49]. However, the main disadvantage of the most existing methods is noises in spectral data (e.g., shadows or sea reflections) that can cause significant extraction errors [14].

Table 1. Review of various existing remote sensing coastline extraction methods.

\begin{tabular}{|c|c|c|c|c|}
\hline $\begin{array}{l}\text { Case Study } \\
\text { (Authors) }\end{array}$ & $\begin{array}{l}\text { Coastline Extraction } \\
\text { Method Type }\end{array}$ & Study Area $\left(\mathbf{k m}^{2}\right)$ & Input Data & Limitations \\
\hline [24] & $\begin{array}{l}\text { Semiautomatic } \\
\text { (histogram threshold/ } \\
\text { frequency band ratio) }\end{array}$ & 5100 & $\begin{array}{l}\text { Low-resolution imagery } \\
\text { (Thematic Mapper (TM); } \\
\text { Enhanced Thematic } \\
\text { Mapper (ETM)) }\end{array}$ & $\begin{array}{l}\text { Not applicable for large } \\
\text { scale mapping [44] }\end{array}$ \\
\hline [14] & $\begin{array}{c}\text { Semiautomatic } \\
\text { (maximum likelihood } \\
\text { method) }\end{array}$ & Few $\mathrm{km}^{2}$ & $\begin{array}{l}\text { High-resolution imagery } \\
\text { (WorldView multispectral } \\
\text { Imagery) }\end{array}$ & $\begin{array}{l}\text { Not applicable for large } \\
\text { scale mapping [44]; } \\
\text { Based only on } \\
\text { spectral information }\end{array}$ \\
\hline [46] & $\begin{array}{l}\text { Semiautomatic } \\
\text { (edge detection } \\
\text { operators) }\end{array}$ & Few $\mathrm{km}^{2}$ & $\begin{array}{l}\text { High-resolution imagery } \\
\text { (Aerial Images/WorldView } \\
\text { multispectral imagery) }\end{array}$ & $\begin{array}{l}\text { Not applicable for large } \\
\text { scale mapping [44]; } \\
\text { Based only on } \\
\text { spectral information }\end{array}$ \\
\hline [12] & $\begin{array}{c}\text { Semiautomatic } \\
\text { (adaptive thresholding) }\end{array}$ & Several hundred km² & $\begin{array}{l}\text { Low-resolution imagery } \\
\quad(\text { Landsat } 8 \mathrm{OLI})\end{array}$ & $\begin{array}{l}\text { Based only on } \\
\text { spectral information }\end{array}$ \\
\hline [15] & $\begin{array}{c}\text { Semiautomatic } \\
\text { (adaptive thresholding) }\end{array}$ & Several thousand $\mathrm{km}^{2}$ & $\begin{array}{l}\begin{array}{l}\text { High-resolution imagery } \\
\text { (Geoeye- }\end{array} \\
\text { 1/Quickbird/WorldView) }\end{array}$ & $\begin{array}{l}\text { Based only on } \\
\text { spectral information }\end{array}$ \\
\hline [16] & $\begin{array}{c}\text { Semiautomatic } \\
\text { (edge detection } \\
\text { operators) }\end{array}$ & Few $\mathrm{km}^{2}$ & $\begin{array}{l}\text { High-resolution imagery } \\
\text { (GF1/GF2/Quickbird/ZY3) }\end{array}$ & $\begin{array}{l}\text { Based only on } \\
\text { spectral information }\end{array}$ \\
\hline [17] & $\begin{array}{c}\text { Semiautomatic } \\
\text { (adaptive thresholding) }\end{array}$ & Few $\mathrm{km}^{2}$ & $\begin{array}{l}\text { Low-resolution imagery } \\
\text { (Landsat TM, ETM+, OLI) }\end{array}$ & $\begin{array}{l}\text { Based only on } \\
\text { spectral information }\end{array}$ \\
\hline [45] & $\begin{array}{c}\text { Semiautomatic } \\
\text { (adaptive thresholding } \\
\text { (edge detection)) }\end{array}$ & Several thousand $\mathrm{km}^{2}$ & $\begin{array}{l}\text { Low-resolution imagery } \\
\text { (Landsat) }\end{array}$ & $\begin{array}{l}\text { Based only on } \\
\text { spectral information }\end{array}$ \\
\hline
\end{tabular}

Therefore, the main objectives of this study were to:

(A) develop and test a new method for coastline extraction from VHR models, which would overcome the above-mentioned problems;

(B) determine the total number, area, and precise insular coastline length of all islands, islets, and rocks or rocks awash within the Iž-Rava island group using the automatic coastline mapping from WorldView2 (WV2)-derived models;

(C) validate the accuracy of coastline extraction from WV-derived imagery and DSM in comparison to field-collected reference data.

The Iž-Rava island group was selected because the Croatian coast is very indented, and as such, it serves as a very good study area for the validation of the newly developed coastal extraction tool (CET). According to the up-to-date, most detailed produced coastline mapping [50], Croatia has 1246 islands, islets, and rocks or rocks awash, with a total insular coastline length of $4398 \mathrm{~km}$.

However, this coastline mapping was based on the digitalization of coastlines from the official state topographic map created for the whole Republic of Croatia in 1:25,000 scale (TM25) [51]. Therefore, it can be assumed that the actual insular coastline length is significantly longer and that the total number of rocks and rocks awash is probably higher. Furthermore, WV stereo and multispectral imagery has not been, until now, used for automated mapping of coastline in Croatia. 


\section{Study Area}

The study site encompasses an area of $78.59 \mathrm{~km}^{2}$, covering the Iž-Rava island group, situated within the Northern Dalmatian archipelago, Croatia [52]. The Iž-Rava island group consists of two larger islands-Iž and Rava-and over a dozen smaller islets and rocks or rocks awash (Figure 2). The current appearance is a result of a complex interaction of prolonged tectonic activity and the last transgression (Late Pleistocene-Holocene) of the Adriatic Sea [53]. The long and indented coastline of the Iž-Rava island group presents a perfect study area for testing and validation of automated coastline extraction methods.

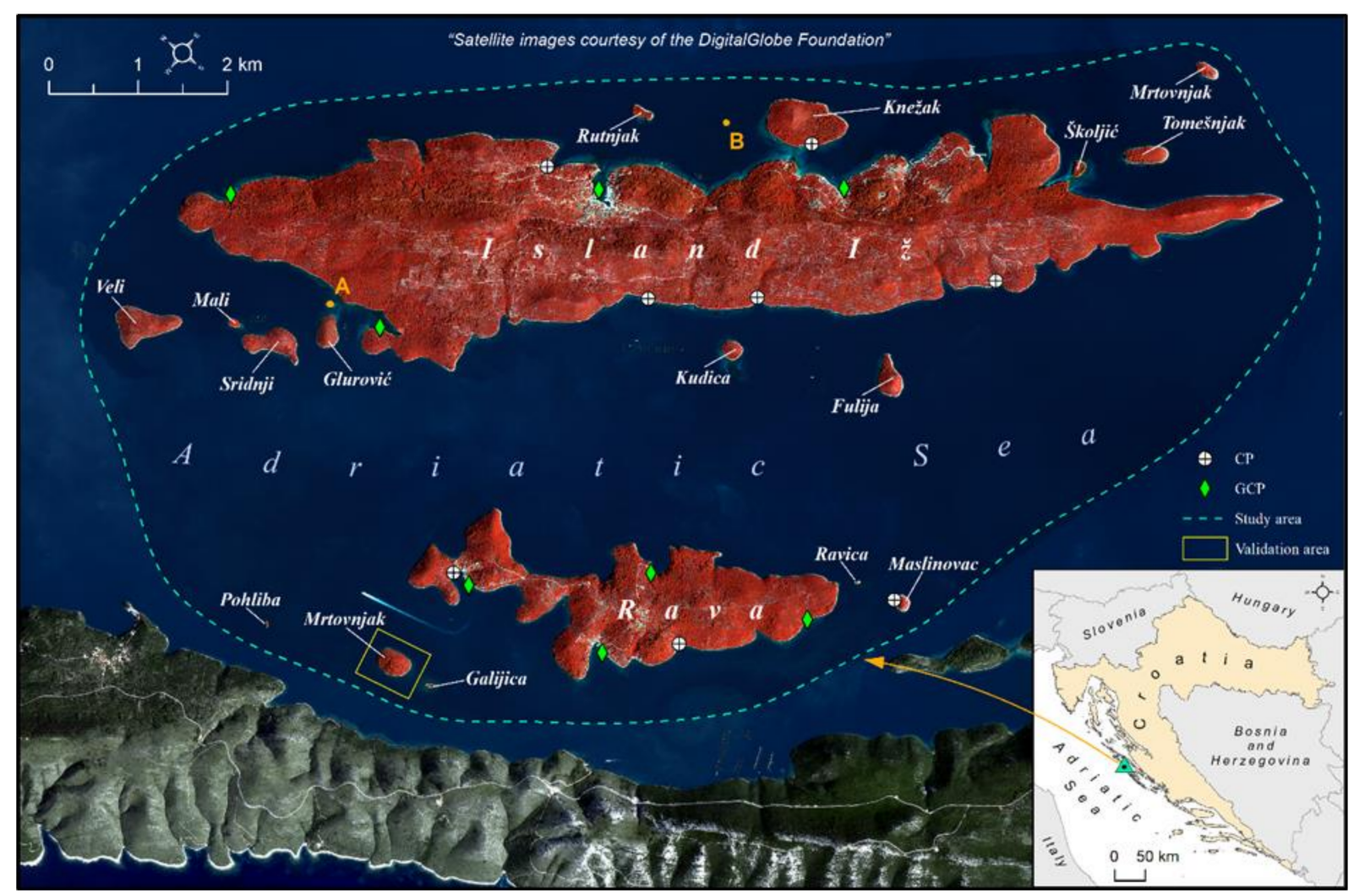

Figure 2. Multispectral Worldview-2 image of study area covering the Iž-Rava island group, Northern Dalmatian Archipelago, Croatia.

\section{Materials and Methods}

\subsection{WorldView-2 (WV2) Multispectral Imagery Preprocessing}

Commercial multispectral Standard 2A WV2 imagery was provided to authors through the DigitalGlobe Foundation [54]. Single multispectral ( $2 \mathrm{~m}$ spatial resolution) and panchromatic ( $0.5 \mathrm{~m}$ spatial resolution) WV2 satellite image acquired on October $28 \mathrm{th}, 2016$, covering the whole Iž-Rava island group, was used as the main data for the extraction and mapping of coastlines. In order to improve geometric, spatial, and radiometric characteristics of given $\mathrm{WV}-2$ images, the following three preprocessing steps were performed: (1) radiometric correction; (2) image pansharpening; and (3) image geometric correction.

The (1) radiometric correction was based on atmospheric correction performed in Geomatica Focus 2018 software, using the ATCOR ground reflectance workflow. ATCOR is an atmospheric correction method that reduces various illumination and atmospheric induced effects on satellite imagery [55]. It is often used for the preprocessing of WV imagery [56-58]. User-defined parameters of ATCOR were adjusted in regard to provided imagery metadata (e.g., sensor type, solar zenith and azimuth, acquisition date, etc.).

After radiometric correction, multispectral and panchromatic WV-2 images were (2) pansharpened. Currently, there is a large number of pansharpening algorithms, which 
differ in terms of fusion quality and induced spectral distortions [59]. One of the most common pansharpening algorithms, which was specially designed for WV imagery, is the hyperspherical color space (HCS) resolution merge algorithm [60], which is implemented within Erdas Imagine 2018 software. This pansharpening algorithm was used for the fusion of multispectral and panchromatic images and the creation of a very high resolution $(0.5 \mathrm{~m})$ multispectral image (WV-2 MS) of our study area.

WV-2 Standard 2A imagery has 5m CE90/LE90 absolute horizontal accuracy specification with $2.3 \mathrm{~m}$ RMSE if acquired at less than 30 degrees off NADIR and excluding terrain effects $[54,61,62]$. According to the imagery metadata, the chosen imagery was acquired at 27.5 mean off NADIR angle with coarse DEM terrain correction applied. Therefore, claimed horizontal accuracy should be correct within the whole study area. Nevertheless, such horizontal geolocation accuracy is not sufficient for most applications that require the highest level of accuracy [58]. In order to further improve (3) the geometric accuracy of chosen imagery, several ground control points (GCPs) were introduced. Precise coordinates of GCPs were collected during the field survey with Stonex S10 RTK-GPS. The collected coordinates were harmonized according to the available tidal data. In total, 35 different GCPs scattered throughout the whole study area were collected. A pansharpened WV-2 image was geometrically corrected according to the collected GCPs through the rubber sheeting method, represented by a spline transformation in ArcGIS 10.1 software [63]. As a result of applied preprocessing, a single very high resolution $(0.5 \mathrm{~m})$ multispectral image of the whole study area was created (WV-MS).

\subsection{Derivation of High-Resolution DSM from WV-2 Stereo-Pairs}

Commercial ortho-ready standard level-2A (OR2A) stereo WV-2 imagery was provided to authors through the DigitalGlobe Foundation [54]. A stereo-pair of WV-1 OR2A along-track panchromatic images acquired on 28 March 2017 was used for the derivation of a high-resolution digital surface model (DSM) of the study area. The creation of the DSM was performed with the Geomatica OrthoEngine 2018 software. OR2A imagery is the most suitable type of WV imagery for the creation of high-resolution DSMs [62]. Optical satellite modeling mathematical model was used for the correlation of image pixels with correct locations on the ground, where the correlation was based on vendor-provided and image-extracted rational polynomial coefficients (RPCs). WV image correlation was based on RPCs provided with WV OR2A stereo imagery and zero-order polynomial adjustment, which has been proven as a reliable method for DSM extraction [62,64-66]. Selected stereo pairs were related through automatic detection and collection of tie points (TP) within overlapping image areas. In total, the automatic collection resulted in 159 TPs collected across the overlapping stereo-pair imagery. Additionally, systematic compensation of RPC-induced errors and improvement of overall image exterior orientation was carried through a manual collection of ground control points (GCPs). In total, 8 ground control points (GCs) and 8 checkpoints (CP) were added manually throughout the study area (Figure 2). RMSE of the introduced GCPs, CPs, and TPs is given in Table 2.

Table 2. RMSE reported for GCPs, CPs and TPs used for the creation of the WV-1-derived DSM of study area.

\begin{tabular}{cccccc}
\hline Point Type & $\mathbf{N}_{\mathbf{o}}$ & RMSE X (m) & RMSE Y (m) & RMSE Z (m) & MEAN RMSE (m) \\
\hline GCP & 8 & 0.403 & 0.684 & 0.484 & 0.524 \\
CP & 8 & 0.398 & 0.751 & 0.749 & 0.633 \\
TP & 159 & 0.063 & 0.016 & 0.013 & 0.031 \\
\hline
\end{tabular}

The collected GCPs and TPs were used for bundle adjustment and the creation of an epipolar image, which is required for the final extraction of the DSM. The last step of the DSM creation covered automated DSM extraction, which was based on the semi-global matching (SGM) method, with a minimal pixel sampling interval and low smoothing level. 
As a result of the applied processing, the high-resolution $(1 \mathrm{~m})$ digital surface model of the study area was created (WV-DSM).

\subsection{Development of Coastline Extration Tool (CET)}

The CET is developed within the ModelBuilder extension of ArcGIS 10.1 software. The workflow of the CET is very straightforward, as the whole processing process can be divided into main four steps: a selection of input data and the creation of spectral indices (1); definition of user-defined thresholds (2); extraction of preliminary coastline models (3); and final coastline model aggregation (4) (Figure 3).

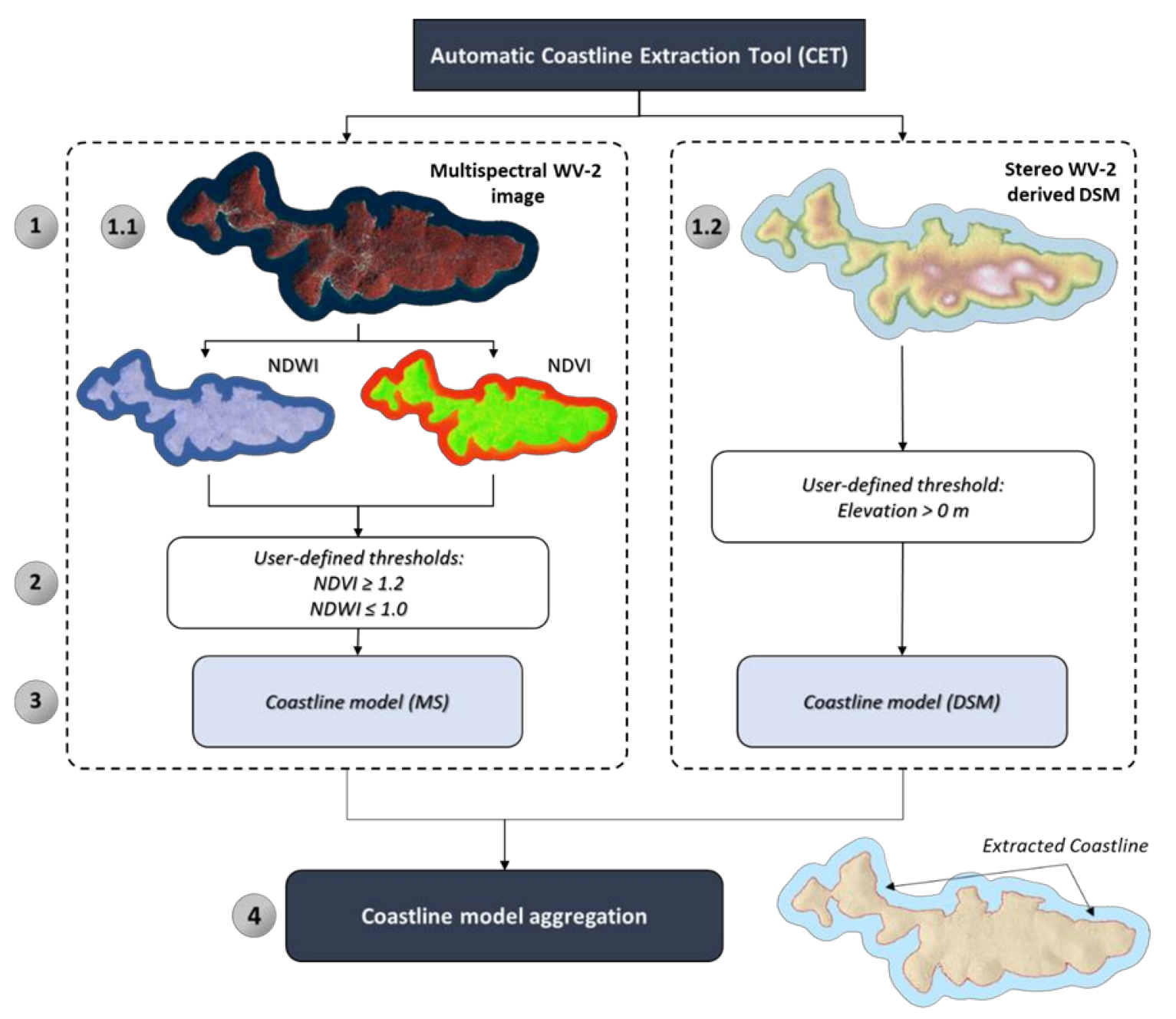

Figure 3. Methodological framework of the automatic coastline extraction tool (CET) development.

In the first step (1), the user defines the input data for CET, where specific spectral bands of multispectral image and corresponding DSM have to be selected. Unlike already existing methods (Table 1), which only use spectral information for the extraction of coastlines, CET uses both spectral and elevation information. While three spectral bands (coastal (C), red (R), and near-infrared 2 (NIR2)) from selected multispectral image (1.1.) are used for the calculation of specific spectral indices, the selected DSM (1.2.) adds the optional possibility to use elevation information for coastline extraction. Spectral indices used for the extraction of coastline are the Normalized Difference Vegetation Index (NDVI) and the Normalized Difference Water Index (NDWI), as those were already used for successful 
coastal extraction in some previous research [5,14]. NDVI and NDWI spectral indices were calculated according to the following equations [14]:

$$
\begin{aligned}
& N D V I=\frac{N I R 2-R}{N I R 2+R} \\
& N D W I=\frac{C-N I R 2}{C+N I R 2}
\end{aligned}
$$

In the second step (2), users can manually adjust the thresholds for the extraction of preliminary coastlines from calculated spectral indices (NDWI and NDVI) and selected DSM. Manual adjustment of thresholds is optional, as users can adjust thresholds in regard to specific characteristics of their study area. For example, if applying CET for extraction of coastline of lakes, which are located at elevations higher than sea level (e.g., $100 \mathrm{~m}$ above sea level), the user can adjust the elevation extraction threshold accordingly. If not specified otherwise, default threshold values are used ( $\geq-0.2$ for NDVI; $\leq-0.2$ for NDWI and $>0$ for DSM) for coastline extraction.

After the definition of extraction thresholds, two preliminary coastline models are created from spectral indices and the DSM (3). The first preliminary coastline model is extracted from the NDVI and NDWI, while the second one is extracted from the DSM.

The last step (4) includes the aggregation of two preliminary models into a single final coastline model. Within this step, the user can manually define the minimal level of detection $\left(L O D_{\min }\right)$ for coastline extraction. $L O D_{\min }$ represents the smallest unit of area that the CET will automatically extract, which should be defined in regards to the spatial resolution of the input data (Figure 3-1.1. and 1.2). The definition of $L O D_{\min }$ allows the automatic removal of all detected areas that are smaller than a defined value, thus automatically removing most of the areas falsely detected as land (e.g., boats, spectral reflections, etc.). Since the spatial resolution of used WV models was $0.5 \mathrm{~m}$ for WV-MS and $1 \mathrm{~m}$ for WV-DSM, the value of $\mathbf{L O D}_{\min }$ was set to $5 \mathrm{~m}^{2}$. However, it should be emphasized that the sizes of the smallest island, islet, rock, or rocks awash within the study area have to be considered before the definition of $L O D_{\text {min }}$. If the defined value is too high, some smaller islands could be potentially removed.

The results of the CET tool should always be manually checked and verified. Therefore, all features extracted by CET were visually checked, and all objects that do not represent land were manually removed from the results. Detailed schematic representation of the developed tool is given in Supplementary Figure S1.

\subsection{Field Acquisition and Processing of UAV Reference Data}

Accuracy validation was performed through a comparison of the coastline derived by the CET from WV-derived models with the coastline derived by the CET from reference data (multispectral UAV photogrammetric survey). Field acquisition of imagery required for the derivation of reference models was done using the UAV photogrammetric survey, carried over the validation area on 13 September 2019.

A UAV photogrammetric multispectral survey was conducted with a functionally assembled system-MAPS (multispectral aerophotogrammetric system), comprised of DJI Matrice 600 PRO UAV (Figure 4A), Gremsy T1 gimbal (Figure 4B), and MicaSense RedEdge $M X$ multispectral camera (Figure 4C-1). Due to the advanced flight capabilities of DJI Matrice $600 \mathrm{PRO}$, the assembled system is capable of conducting complex photogrammetric surveys [67], while, at the same time, the integrated Gremsy T1 gimbal ensures constant stabilization and positioning of the multispectral camera. The integrated MicaSense RedEdge $M X$ camera allows the acquisition of multispectral images with the simultaneous collection of five different spectral bands (R, G, B, RedEdge, NIR) [68]. 


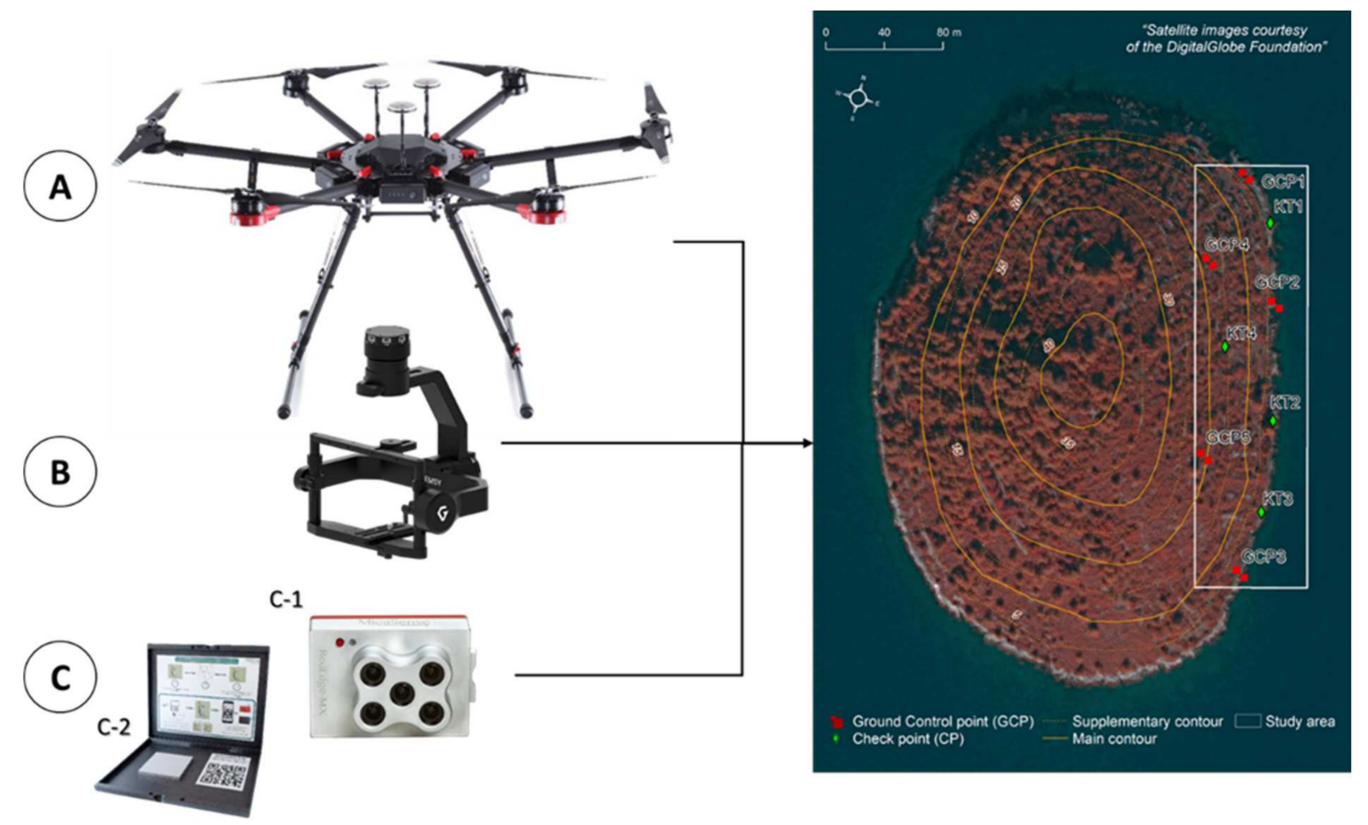

Figure 4. Different components (A,B,C-1,C-2) functionally integrated into MAPS (left); spatial extent of the multispectral UAV photogrammetric survey (right).

The spatial extent and parameters of the photogrammetric flight mission were planned and automated within the Universal Ground Control Software 3.3.348 (UgCS) application. The ground sampling distance (GSD) of the planned flight mission was set to $5 \mathrm{~cm}$, forward and side overlap were set to $75 \%$, constant flight height was set to $73.3 \mathrm{~m}$ above the ground level, and double-grid flight profiles were chosen during the planning of flight missions (Figure 5). In order to improve the overall georeferencing of created models, nine GCPs were introduced within the validation area, whose precise coordinates were collected using Stonex S10 RTK-GNSS and harmonized according to the available tidal data. A multispectral camera was calibrated using the calibration panel (Figure 4C-2) before and after the conducted flight mission. In total, 2319 multispectral images were collected within the carried survey.

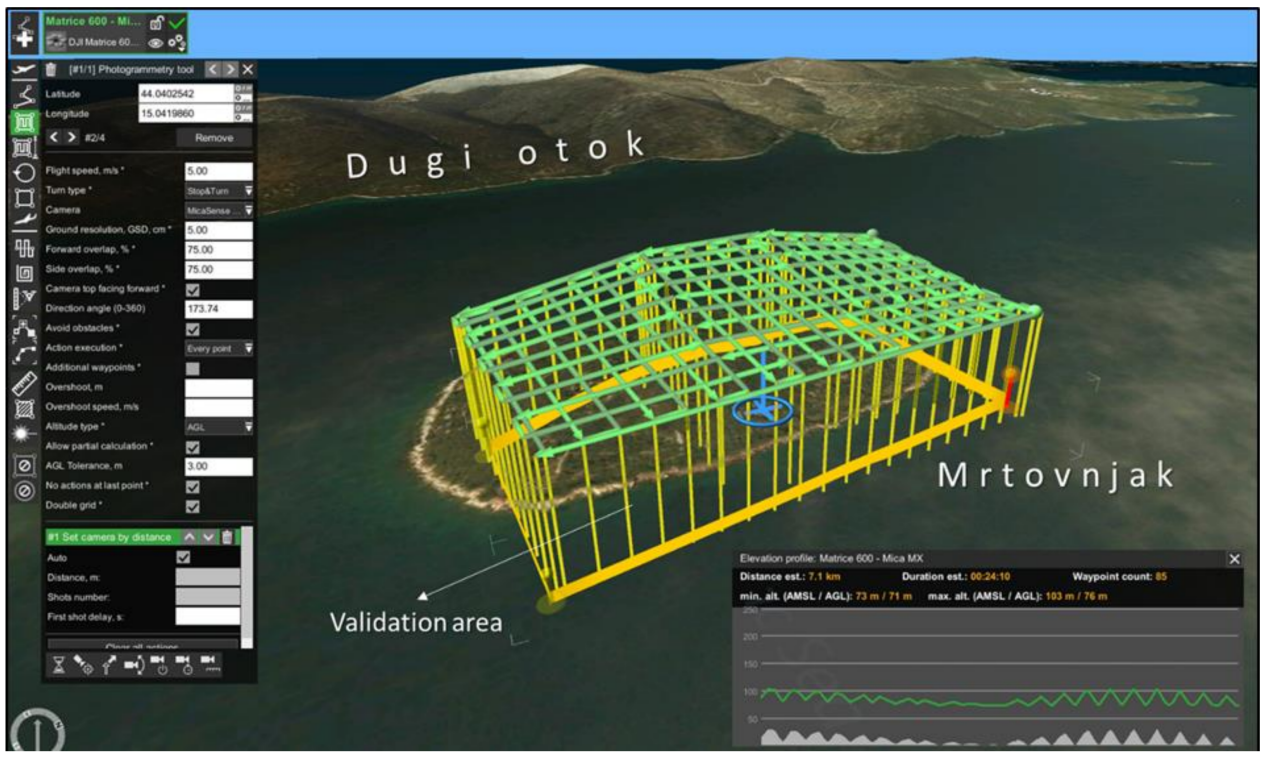

Figure 5. Parameters and the spatial extent of the multispectral UAV photogrammetric survey planned over the validation area within UgCS. 
The multispectral imagery was processed using the Agisoft Metashape 1.5.1 commercial software, which uses structure-from-motion (SfM) and multiview-stereo technology for the creation of high-detailed centimeter resolution models. The imagery processing methodology was adjusted according to the recommendations given in similar research [69]. Some of the user-defined parameters used for the creation of VHR models in Metashape are given in Table 3. In total, nine GCPs were added to the Metashape, from which five were used in Metashape as control points and four as checkpoints.

Table 3. User-defined settings used during the creation of VHR models (left) and reported RMSE in control and checkpoints (right).

\begin{tabular}{cccc}
\hline Parameter & User-Defined Settings & Point Type & Total RMSE (cm) \\
\hline & Accuracy: High & & \\
& Generic preselection: Yes & & \\
Alignment parameters & Reference preselection: & Control points & 9.68 \\
& Yes & & \\
& Key point limit: 40,000 & & \\
& Tie point limit: 10,000 & & 10.29 \\
Dense point cloud: & Quality: High & Check points & \\
reconstruction parameters & Filtering mode: & & \\
& Aggressive &
\end{tabular}

Image processing workflow resulted in the derivation of a single 5-band multispectral image (UAV-MS) and digital surface model (UAV-DSM) of validation area, with a spatial resolution of $5 \mathrm{~cm}$. Then, developed CET was applied for the extraction of the coastline from these created reference UAV-MS and UAV-DSM models. Since the used multispectral camera (MicaSense RedEdge MX) did not have Coastal and NIR2 spectral bends, those were replaced with Green and NIR bands for the calculation of NDVI and NDWI:

$$
\begin{aligned}
& N D V I=\frac{N I R-R}{N I R+R} \\
& N D W I=\frac{G-N I R}{G+N I R}
\end{aligned}
$$

Furthermore, user-defined thresholds within the CET had to be adjusted accordingly. The user-defined threshold for the NDVI was set to $\geq 0.5$, while NDWI and DSM remained identical to default thresholds ( $\leq-0.2$ for NDWI and $>0$ for DSM).

\subsection{Extraction and Validation of CET-WV Coastlines}

In order to evaluate the newly developed coastline mapping technique (CET), it was necessary to compare its results with the currently available methods and data for the study site. Therefore, the automated extraction of all coastlines within the study area was done using CET. Then, the extracted coastlines (CET-WV) for the whole study site were compared with two different datasets (Figure 6A):

(A) coastlines from the Topographic map of the Republic of Croatia $(1: 25,000)$;

(B) coastlines derived from preprocessed multispectral WV-2 image (WV-MS) by a tool developed in [14].

The semi-automatic extraction of coastlines from existing state official topographic maps (A) was performed with ArcScan extension of ArcGIS 10.1 software. Automatic derivation of coastlines by an open-source tool (B) was performed in Erdas Imagine 2018 software, using the provided open-source tool [70]. This comparison (B) is especially important because it demonstrates how detailed and accurate the developed CET method is in relation to similar existing methods for automated coastline extraction and to the officially available data. 

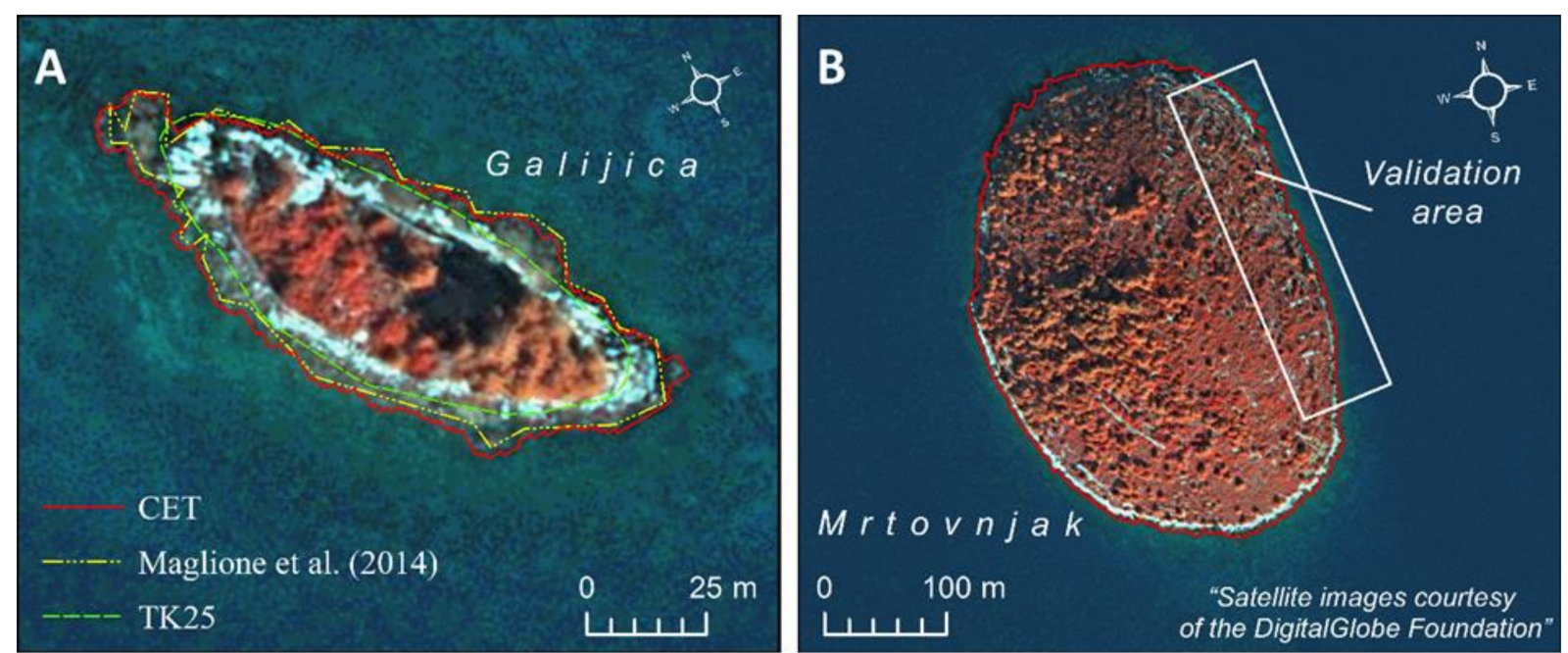

Figure 6. Comparison of CET-WV with two different datasets (A); location of the validation area within Mrtovnjak island (B).

A further validation assessment of CET-WV coastlines was performed within the second chosen validation area, which encompassed the $300 \mathrm{~m}$ long segment of the Mrtovnjak island coastline (Figure 6B).

This assessment was based on a comparison of the CET-WV-derived coastline with the coastline derived from reference data (CET-UAV) collected within the field UAV photogrammetric survey (Figure 5). CET-UAV and CET-WV coastlines were extracted from datasets collected on different dates. Therefore, the derived models (UAV and WV) used for the extraction of coastlines were harmonized by available tidal data according to the determined tidal difference, which was $9.6 \mathrm{~cm}$ [Tidal data for chosen dates (28 October 2016 and 13 September 2019) was provided by the Hydrographic Institute of the Republic of Croatia (๑) HHI) from the tidal gauge in Zadar]. The reference dataset (CET-UAV) represents the coastline derived by the CET from the UAV photogrammetry-derived multispectral image (UAV-MS) and the digital surface model (UAV-DSM). Models derived from the UAV survey have a significantly higher spatial resolution $(5 \mathrm{~cm})$ than WV-derived models $(50 \mathrm{~cm}$ for WV-MS and $100 \mathrm{~cm}$ for WV-DSM). Thus, the corresponding coastline can be used as reference data for the validation of the accuracy and quality of CET-WV-derived coastlines. Since, in this case, CET is used for coastline extraction from both validated models (WV) and reference models (UAV), this validation rather represents the difference in the accuracy of the models used for coastline extraction (WV vs. UAV). Thus, the conducted validation evaluates the potential of WV-derived models for accurate large-scale coastline mapping.

The validation of horizontal accuracy of the CET-WV-derived coastline was performed by Digital Shoreline Analysis System v. 5.0 (DSAS), an add-in published by the United States Geological Survey (USGS) for the ESRI ArcGIS v.10 software [71]. The DSAS extension allows the user to define a reference line (baseline), which serves as the basis for projecting transects perpendicular to that baseline (Figure 7). Mainly, DSAS is used for the calculation of coastline displacement [72] using the traces of several historical coastlines, attributed to different time intervals, where DSAS simply measures the distance between the baseline and the intersections of the coastlines within each transect, e.g., [73,74]. These measurements provide quantitative information and different useful statistical data about the change in position of the coastlines within the surveyed period. 


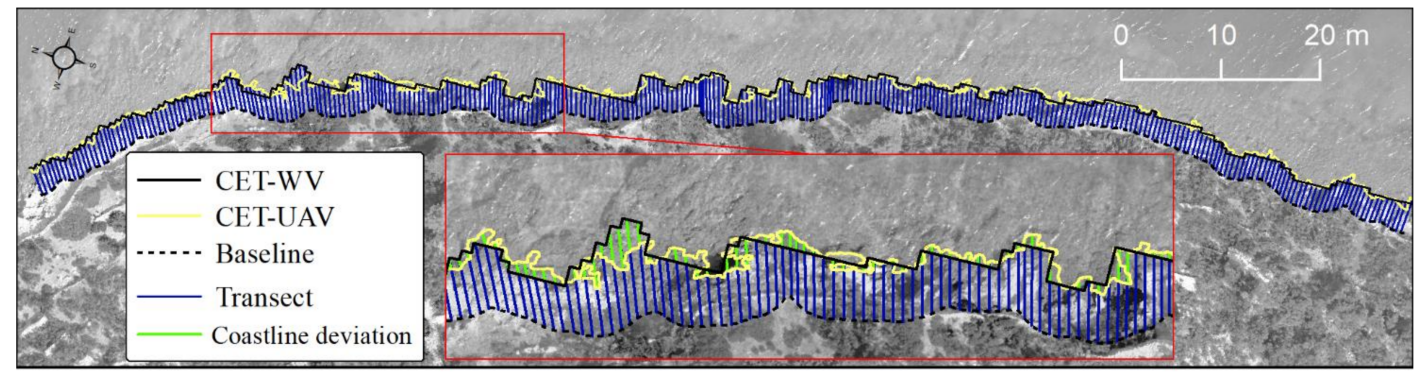

Figure 7. The calculation of the coastline deviation (green) for the CET-WV coastline within the transects created by DSAS.

Within this research, the DSAS extension was used for a different purpose. The horizontal accuracy of the CET-WV-derived coastline was calculated as the deviation between the reference CET-UAV coastline and evaluated CET-WV coastline. Used baseline was derived from a reference CET-UAV coastline, as a buffer line projected $5 \mathrm{~m}$ onshore from the original CET-UAV line, which was additionally generalized (smoothed) to represent only the rough contours of the initial CET-UAV coastline. From this baseline, perpendicular transects were projected towards the CET-UAV and CET-WV coastlines with $1 \mathrm{~m}$ spacing, where the exact coastline deviation was calculated within every individual transect (Figure 7).

\section{Results}

\subsection{Results of CET Application on WV-Derived Models}

The application of the CET resulted in the extraction of 235 separate features, which were larger than the defined $L O D_{\min }\left(5 \mathrm{~m}^{2}\right)$. However, most of these detected features were objects that do not actually represent land (e.g., small boats, waves, fish farms, etc.), and as such, they were manually removed from the results. In total, 20 objects remained after visual verification, which represents true islands, islets, and rocks of the Iž-Rava island group. Coastline lengths, as well as the total area of extracted islands, islets, and rocks from the Iž-Rava island group, are given in Tables 4 and 5.

Table 4. Extracted coastline lengths ( $\mathrm{m})$ of the Iž-Rava island group.

\begin{tabular}{|c|c|c|c|c|}
\hline \multirow{2}{*}{ ID } & \multirow{2}{*}{ Island Name } & \multicolumn{3}{|c|}{ Coastline Length (m) } \\
\hline & & TM $(1: 25,000)$ & [14] & CET-WV \\
\hline 1 & $I \check{z}$ & $36,546.77$ & $44,461.74$ & $49,754.00$ \\
\hline 2 & Rava & $16,662.97$ & $23,765.53$ & $22,512.00$ \\
\hline 3 & Knežak & 2415.48 & 3146.12 & 3310.00 \\
\hline 4 & Beli & 1996.52 & 2182.22 & 2678.00 \\
\hline 5 & Sridnji & 1800.95 & 2124.16 & 2406.00 \\
\hline 6 & Fulija & 1239.08 & 1761.92 & 1688.00 \\
\hline 7 & Tomešnjak & 1192.04 & 1423.79 & 1514.00 \\
\hline 8 & Mrtovnjak (Rava) & 1108.53 & 1578.99 & 1660.00 \\
\hline 9 & Glurović & 997.55 & 1225.01 & 1372.00 \\
\hline 10 & 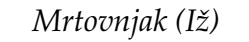 & 707.59 & 899.98 & 944.00 \\
\hline 11 & Kudica & 691.41 & 745.22 & 932.00 \\
\hline 12 & Rutnjak & 681.47 & 898.27 & 774.00 \\
\hline 13 & Maslinovac & 592.10 & 628.07 & 908.00 \\
\hline 14 & Školjić & 536.58 & 730.71 & 762.00 \\
\hline 15 & Mali & 376.20 & 411.62 & 520.00 \\
\hline 16 & Galijica & 248.14 & 345.45 & 416.00 \\
\hline 17 & Pohliba & 177.19 & 244.80 & 302.00 \\
\hline 18 & Ravica & 173.11 & 215.63 & 258.00 \\
\hline 19 & Sika & - & 24.99 & 38.00 \\
\hline 20 & Garofulin & - & 9.72 & 14.00 \\
\hline \multicolumn{2}{|c|}{ Total coastline length (m) } & $68,143.67$ & $86,823.93$ & $92,762.00$ \\
\hline
\end{tabular}


Table 5. Extracted area of the Iž-Rava island group (Red-labeled islands characterize a large presence of shadow-induced errors, which significantly raised the total island area extracted by the tool developed in [14]).

\begin{tabular}{|c|c|c|c|c|c|c|c|}
\hline \multirow[b]{2}{*}{ ID } & \multirow{2}{*}{$\begin{array}{l}\text { Island } \\
\text { Name }\end{array}$} & \multicolumn{3}{|c|}{ Total Area (ha) } & \multicolumn{3}{|c|}{ Total Area $\left(\mathrm{km}^{2}\right)$} \\
\hline & & $\begin{array}{c}\text { TM } \\
(1: 25,000)\end{array}$ & [14] & CET-WV & $\begin{array}{c}\text { TM } \\
(1: 25,000)\end{array}$ & [14] & CET-WV \\
\hline 1 & $I \check{z}$ & 1655.48 & 1658.08 & 1662.25 & 16.555 & 16.581 & 16.622 \\
\hline 2 & Rava & 363.76 & 360.83 & 367.93 & 3.638 & 3.608 & 3.679 \\
\hline 3 & Knežak & 36.78 & 36.33 & 36.90 & 0.368 & 0.363 & 0.369 \\
\hline 4 & Beli & 20.04 & 20.32 & 20.40 & 0.200 & 0.203 & 0.204 \\
\hline 5 & Sridnji & 13.76 & 14.16 & 14.35 & 0.138 & 0.142 & 0.143 \\
\hline 6 & Fulija & 9.03 & 8.85 & 9.28 & 0.090 & 0.089 & 0.093 \\
\hline 7 & Tomešnjak & 8.98 & 8.21 & 9.12 & 0.083 & 0.082 & 0.091 \\
\hline 8 & $\begin{array}{c}\text { Mrtovnjak } \\
\text { (Rava) }\end{array}$ & 8.32 & 8.72 & 8.33 & 0.090 & 0.087 & 0.083 \\
\hline 9 & Glurović & 6.85 & 6.91 & 7.11 & 0.068 & 0.069 & 0.071 \\
\hline 10 & $\begin{array}{l}\text { Mrtovnjak } \\
\text { (Iž) }\end{array}$ & 3.69 & 3.30 & 3.95 & 0.033 & 0.033 & 0.040 \\
\hline 11 & Kudica & 3.32 & 3.93 & 3.40 & 0.037 & 0.039 & 0.034 \\
\hline 12 & Rutnjak & 2.69 & 2.51 & 2.72 & 0.027 & 0.025 & 0.027 \\
\hline 13 & Maslinovac & 2.44 & 2.66 & 2.65 & 0.0244 & 0.0266 & 0.0265 \\
\hline 14 & Školjić & 2.03 & 2.02 & 2.17 & 0.0203 & 0.0202 & 0.0217 \\
\hline 15 & Mali & 0.97 & 1.07 & 1.10 & 0.0097 & 0.0107 & 0.0110 \\
\hline 16 & Galijica & 0.33 & 0.42 & 0.44 & 0.0033 & 0.0042 & 0.0044 \\
\hline 17 & Pohliba & 0.18 & 0.17 & 0.27 & 0.0018 & 0.0017 & 0.0027 \\
\hline 18 & Ravica & 0.17 & 0.21 & 0.23 & 0.0017 & 0.0021 & 0.0023 \\
\hline 19 & Sika & - & 0.002 & 0.005 & - & 0.000020 & 0.000048 \\
\hline 20 & Garofulin & - & 0.0004 & 0.0010 & - & 0.000004 & 0.000010 \\
\hline \multicolumn{2}{|c|}{ Total area } & 2138.81 & 2138.71 & 2152.60 & 21.388 & 21.387 & 21.526 \\
\hline
\end{tabular}

The total length of the CET-WV-extracted coastline within the Iž-Rava group is $92,762 \mathrm{~m}(92.76 \mathrm{~km})$, which is significantly longer than official data [50] and coastline length extracted by another tested tool [14]. In total the CET-WV data is longer for $24,618.33 \mathrm{~m}$ (26.53\% increase) than the coastline length derived from official state TM 1:25,000 maps. CET-WV coastline is significantly longer due to the more detailed extraction and representation of rugged coastline, which is considerably generalized in TM 1:25,000 (Figure 8). Furthermore, the CET-WV-extracted coastline was longer for $5938.07 \mathrm{~m}(6.41 \%)$ than the coastline extracted by the other tested tool from identical WV-derived models.

An increase in the total coastline length of all features within the Iž-Rava island group has also affected the increase in the total area of all mapped islands, islets, and rocks (Table 5). Therefore, the increase in the total area of land features from $21,388 \mathrm{~km}^{2}$ (TM $1: 25,000)$ to $21,526 \mathrm{~km}^{2}$ represents a $0.64 \%$ increase in the total land area of the Iž-Rava island group.

As seen in Table 4, in some cases coastline length of some islands was longer when it was extracted by the other tested tool (Table 4), but this is exclusively the result of errors introduced by shaded areas in the multispectral image (Figure 8). While CET managed to overcome errors induced by shadows, the other tested tool falsely classified most of the shaded areas as water, thus artificially extending the total coastline of affected islands. This is further confirmed with the total area of extracted islands, which is significantly smaller for land features extracted by the other tested tool than for CET-extracted features. Falsely classified shaded areas are affecting the results of the other tested tool to such an extent that the total area of some islands (e.g., Rava, Knežak, Fulija, Tomešnjak, etc.) is smaller within the results of this tool than on generalized TM 1:25,000 maps (Table 5). 


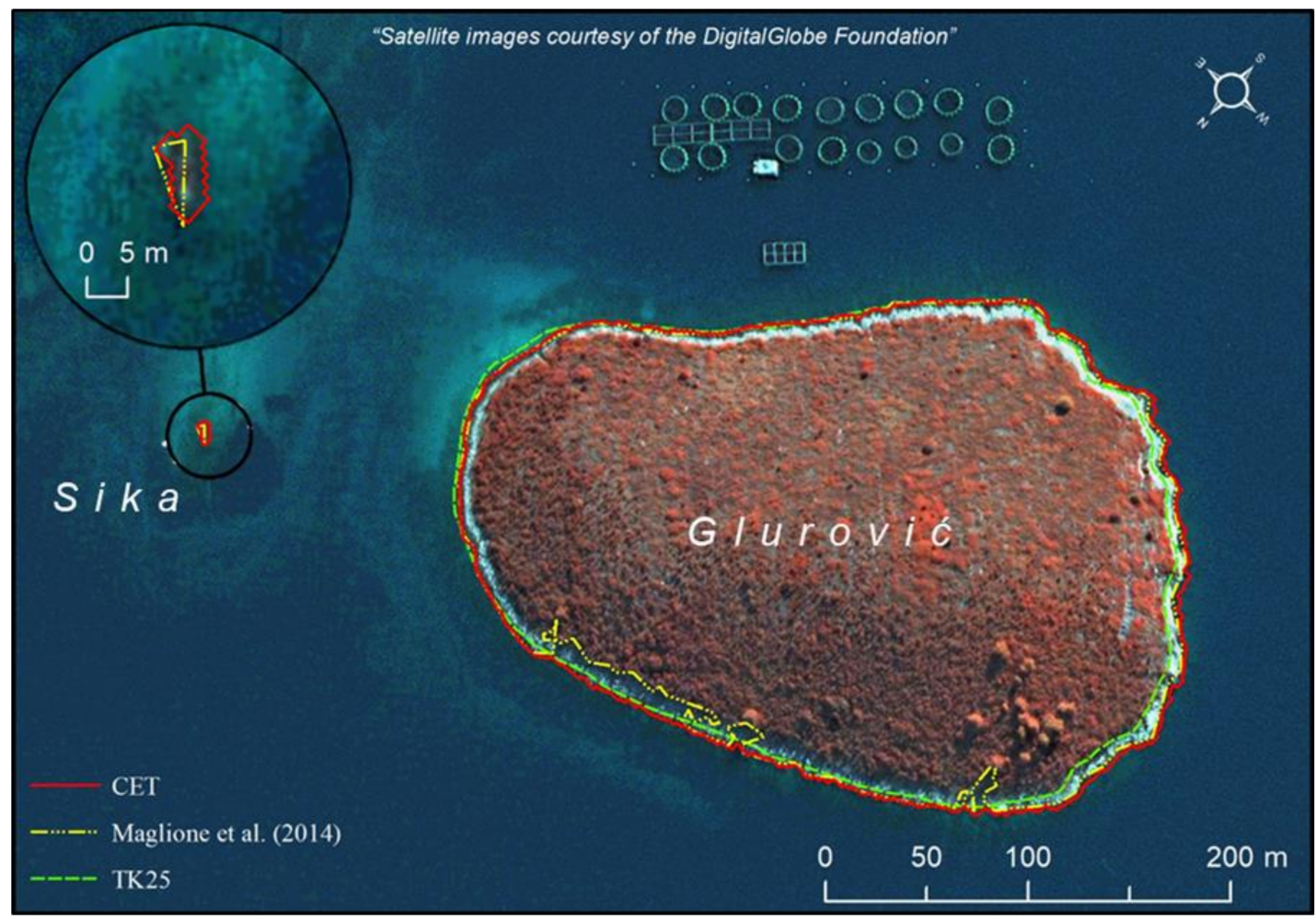

Figure 8. Visual comparison of coastline generalization intensity.

It should be noted that two very small rocks were detected and mapped by CET within the Iž-Rava island group (Figure 2A,B and Figure 9), which have not been mapped during the earlier coastline mapping efforts [50]. Due to their very small size (Sika $=48 \mathrm{~m}^{2}$; Garofulin $=10 \mathrm{~m}^{2}$ ), these rocks have not been detectable within previous mapping efforts, and as a result, they have not been counted in an official number of islands, islets, and rocks or rocks awash in Croatia. As seen in Figure 9. Garofulin $\left(10 \mathrm{~m}^{2}\right)$ is a very small and low rock sticking out from shallow areas between Iž and Knežak islands, which posed a serious threat for local navigation. For that reason, it was originally marked with red paint, while later on, the small light indicator was built on top of it. Sika is by area slightly larger than Garofulin, but it is much lower. The successful detection and mapping of these two very small rocks raised the total number of islands, islets, and rocks within the Iž-Rava island group from 18 to 20 while also raising the total (but obviously not final) official number for the Croatian coast from 1246 to 1248. Both Sika and Garofulin are not represented in TM 1:25000 maps, and therefore have not been mapped and counted within earlier mapping efforts carried within [50].

Compared results are clearly indicating that the developed CET achieved better coastline extraction results, with a significant improvement in the detail of extraction, in regard to both the generalized official state TM 1:25,000 maps and the existing tested tool. Considering that CET was applied within a large area $\left(78.59 \mathrm{~km}^{2}\right)$, covering islands, islets and rocks of different shapes and sizes, the achieved detail and accuracy of coastline extraction are excellent. 

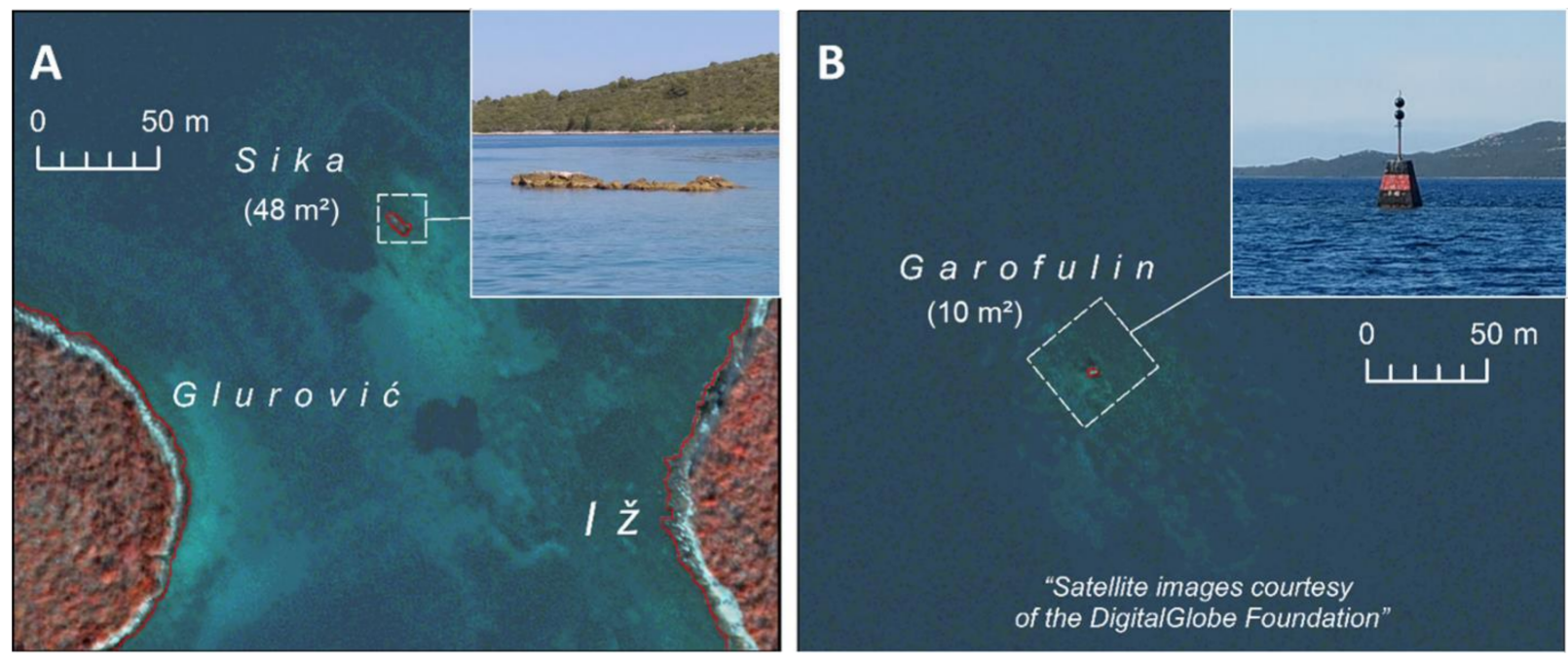

Figure 9. Two very small rocks successfully mapped by CET from WV-derived models.

\subsection{Validation of CET-WV-Extracted Coastline with Reference UAV Data}

The validation of CET-WV-extracted coastline with reference UAV data has shown that a coastline derived from WV models is significantly generalized (Figure 10). Such generalization is mainly the result of the spatial resolution of WV models, which are not detailed enough for the detection and representation of the majority of smaller coastline curvatures. Consequently, the total length of the coastline derived from WV models is considerably shorter than the coastline derived from UAV models. In comparison, the length of the CET-WV coastline is $405.01 \mathrm{~m}$, while the total length of the CET-UAV-extracted coastline is $634.14 \mathrm{~m}$, which is $36.13 \%$ longer. The level of generalization of the CET-WVextracted coastline is furthermore expressed through the difference in the total number of vertices that represent derived coastlines. While the CET-UAV coastline has in total 2930 vertices, the CET-WV coastline has only 240, which is less than $10 \%$ of all vertices of the CET-UAV coastline.

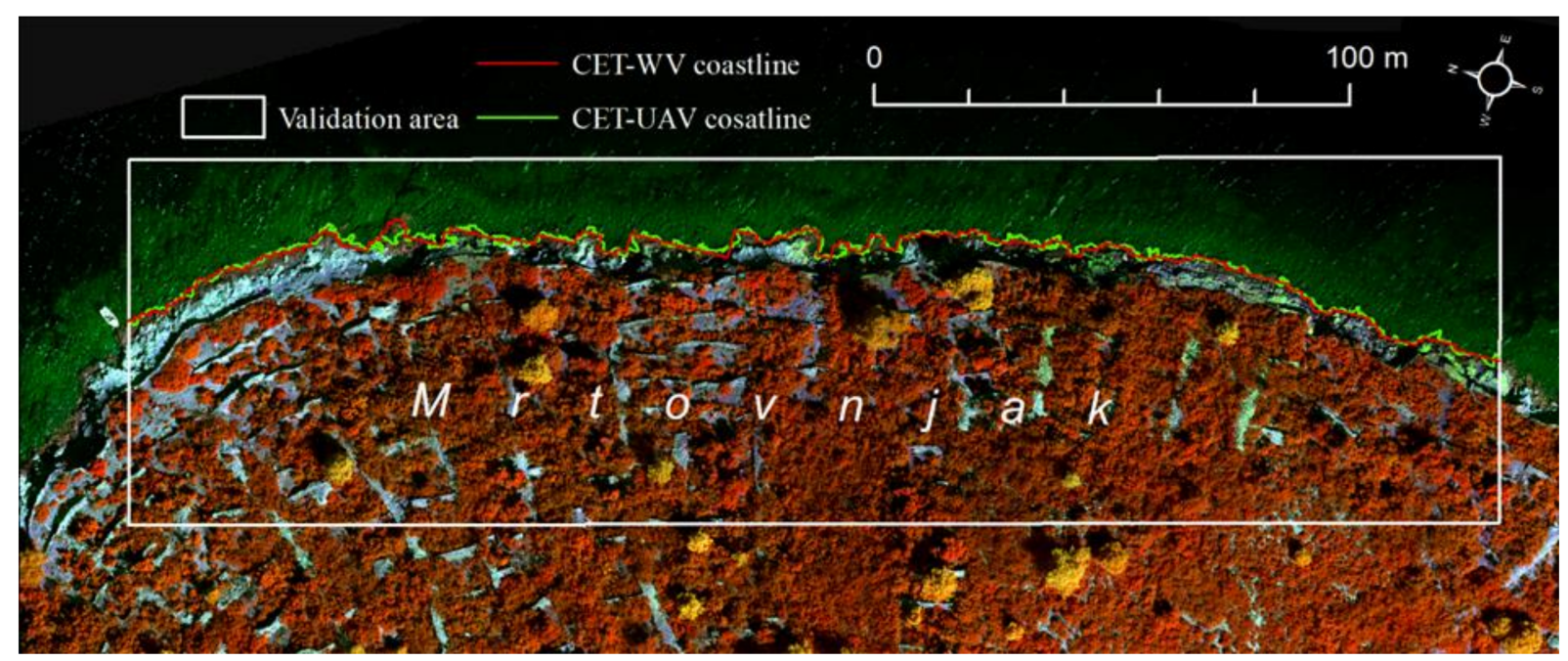

Figure 10. Coastlines within validation area derived by CET from WV-derived (red) and UAV-derived (green) models.

Despite significant generalization, the extracted CET-WV coastline managed to accurately follow and define the predominant shape and direction of the coastline.

This was further confirmed through the conducted validation of the coastline horizontal accuracy. Within the validation performed by DSAS, 310 transects were created in total, 
along the $310.86 \mathrm{~m}$ long baseline. The average calculated deviation of the CET-WV coastline in regard to the reference CET-UAV coastline was $0.73 \mathrm{~m}$, with a maximum deviation reaching up to $5.7 \mathrm{~m}$. Calculated deviation of CET-WV coastline was under $0.68 \mathrm{~m}$ in $49.35 \%$ of all transects, while deviations above $1.13 \mathrm{~m}$ were present within only $8.38 \%$ (26 transects) of all analyzed transects (Figure 11). It should be noted that the highest coastline deviation rates were calculated within very shallow parts of the evaluated coastline, where detected deviations could be related to the fluctuations in Sea level caused by different tidal regimes (between CET-UAV and CET-WV). Calculated deviations have shown that the horizontal accuracy of the CET-WV coastline is very high, which confirms that WV-derived models can serve as a perfect basis for a highly accurate large-scale coastline mapping.

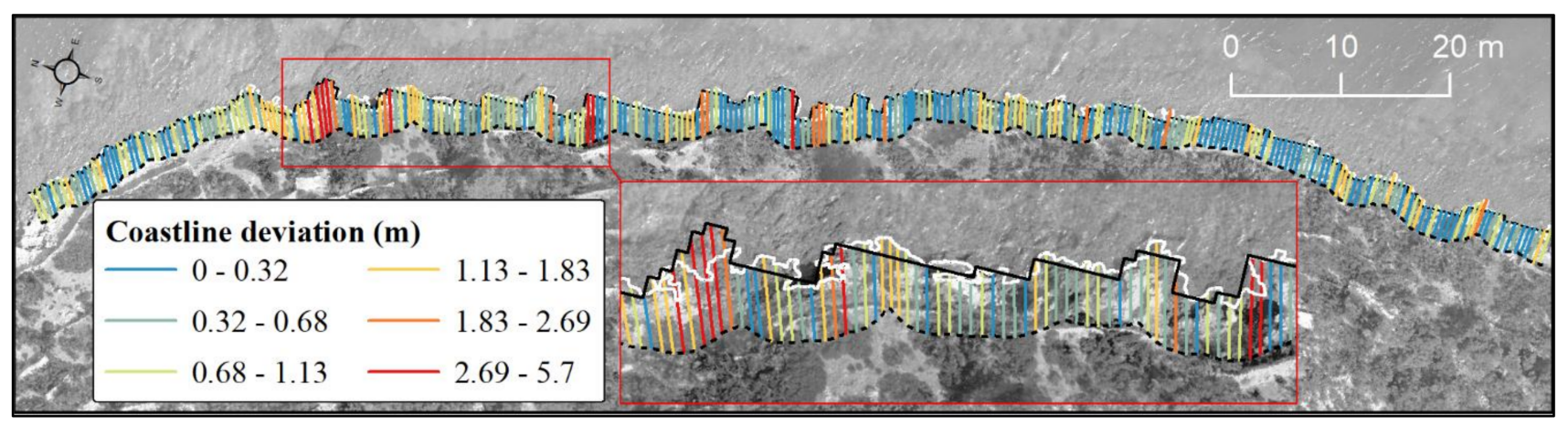

Figure 11. Coastline deviation between evaluated CET-WW and reference CET-UAV coastlines calculated by CET.

Furthermore, the performed validation has shown that the accuracy of the CET coastline extraction within the whole Iž-Rava island group (Section 3.1) would be even better if WV imagery extraction was applied on VHR models created from the UAV photogrammetric data. However, acquisition of such UAV photogrammetric data for the whole study area would require difficult and lengthy field work.

\section{Discussion}

\subsection{Advantages of Developed CET}

4.1.1. Detailed Coastline Mapping and Representation

Coastlines extracted by CET-WV are much less generalized (Figure 8, 12, 13) than coastlines extracted with another tested tool. This is best demonstrated on smaller islands and rock examples (e.g., Sika) (Figure 8). As explained by the coastline paradox, the accuracy of the coastline length calculation is directly related to the level of coastline generalization. Accordingly, CET should be applied in all cases where accurate coastline mapping is required.

\subsubsection{Elimination of Errors Caused by Shadows}

The integrated use of MS-derived spectral and DSM-derived elevation in CET successfully eliminates a majority of errors induced by noises in spectral data (e.g., shadows or sea reflections). While most existing methods for automated coastline extraction, e.g., [14], are characterized by the significant presence of errors in the coastline mapping within shaded areas of the multispectral image, CET managed to achieve high mapping accuracy even within these areas (Figures 12 and 13). Spectral characteristics of shaded areas are more similar to water than to land areas, which is why most existing extraction methods falsely classify those areas as water bodies. As seen in Figures 12 and 13, such shadow-induced errors are falsely extending the total coastline length, while at the same time total area of the affected island is falsely reduced (Table 5: ID 2,3,6,7,10, 12, 14, 17). At the same time, due to the combination of spectral and elevation information, the CET has managed to restrict the influence of such shadow-induced errors and extract the coastline accurately. 
Therefore, CET should be applied in all cases where shadows are present in multispectral imagery, as, within these areas, other methods would not achieve satisfactory results.

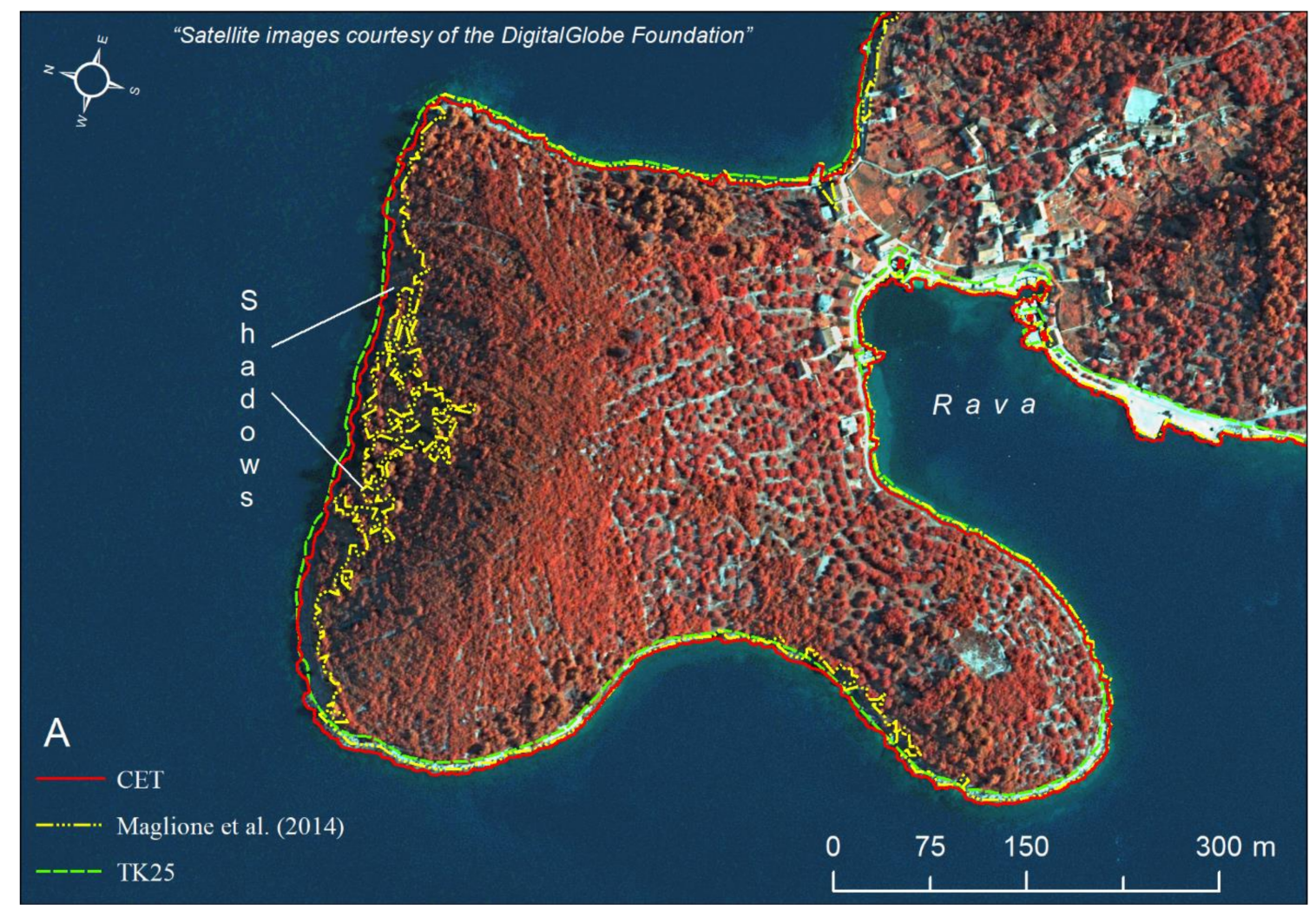

Figure 12. Successful automated extraction of coastline over significantly shaded areas.

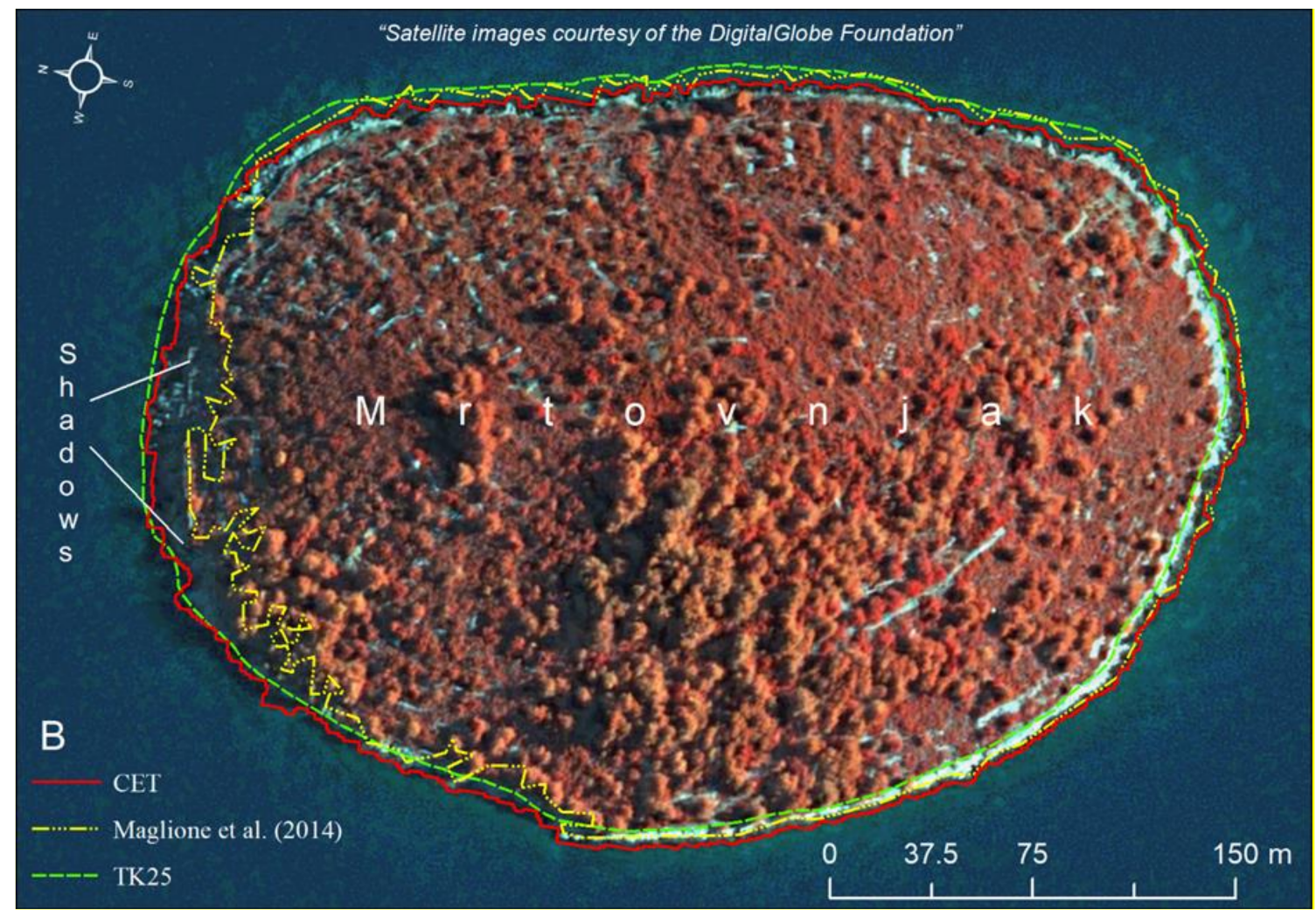

Figure 13. Successful automated extraction of coastline over significantly shaded areas. 


\subsubsection{Wide Range of Other Potential Applications}

Besides coastline mapping, CET can be potentially applied for a wide range of applications. During the automated extraction of the coastline, the CET managed to detect various other objects that can provide potentially valuable information for different applications (Figure 14). For example, the CET has successfully managed to detect very small objects, such as small fishing boats (Figure 14A), or even fast-moving objects, such as speedboats (Figure 14C), and small low-flying aircraft (Figure 14D). Furthermore, CET has successfully mapped most of the existing fish farms within the study area (Figure 14B). The ability to locate and detect such small and fast-moving objects can be crucial for monitoring and protecting coastal areas [75-78]. Automated detection of small fishing vessels can be used for the prevention and control of illegal fishing or can be potentially used for easily and quickly locating missing boats during search and rescue missions. Given the very high temporal (revisit time of 1.1 days [79]) and spatial resolution of WV imagery, the application of CET can provide effective management over very large coastal areas.

\subsubsection{Detection of Spatio-Temporal Changes in Coastline Position}

In this study, CET was applied to the Iž-Rava island group, whose coast is made from coastal erosion-resistant carbonate rocks [53]. Due to carbonate rocks, little erosion-induced spatio-temporal changes can be observed over time. However, if applied for mapping of erosion-prone coastlines (e.g., pebble or sandy coast), CET could be used for accurately monitoring the overall coastline evolution. As accurate coastline extraction represents a basis for the quantification of erosion-induced spatio-temporal changes, CET has great potential for precise mapping of temporal shifts in coastline position.
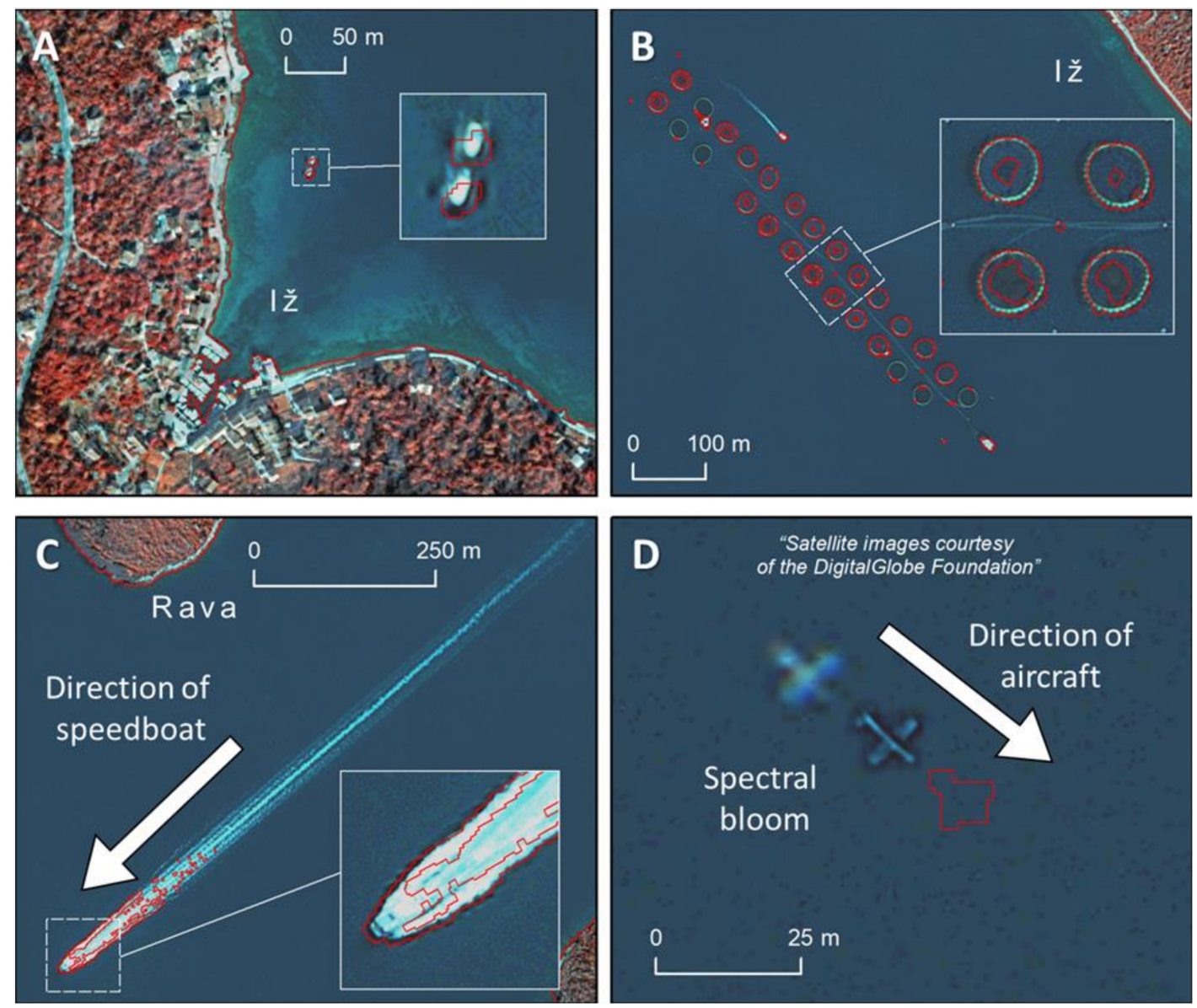

Figure 14. Example of CET application for the detection of small boats (A); the detection and mapping of fish farms (B); the detection of speedboats (C); the detection of aircrafts (D). Spectral bloom is caused by fast-moving objects due to temporal offset of the multispectral sensors of the WV-2 satellite. It can be used for determination of the speed of moving objects [73]. 


\subsubsection{Applicability of CET to Different Data Types}

This study has shown that CET can be successfully applied for accurate extraction and mapping of coastline from various data sources, regardless of spatial resolution. The application of CET within the validation area has demonstrated that CET achieves good mapping results on both high-resolution WV-2-derived models and on VHR models derived from field UAV photogrammetric survey. The compatibility of CET with models with different spatial resolutions allows its flexible application for various researches, ranging from local (few $\mathrm{m}^{2}$ ) to regional scales (few hundred $\mathrm{km}^{2}$ ). Besides WV imagery, CET can be used for all other types of satellite imagery, including open-source data, such as Sentinel or LANDSAT imagery.

\subsection{Limitation of the Developed CET}

Despite the stated advantages, the developed CET has a few limitations, which should be addressed in future research and development. The main shortcoming of CET is the pronounced dependence of coastline extraction accuracy on the input data quality. While CET managed to resolve errors caused by the presence of shadows in multispectral imagery, its extraction accuracy is still, in some cases, affected by spectral information. The presence of artificial objects (e.g., small fishing boats) close to the coast can lead to the overestimation of the extracted coastline. This is especially present within harbors, where anchored boats are regarded by the CET as part of the coast (Figure 15). However, if the whole length of the coastline extracted within the study area is considered, such areas are covering very small portions of the total extracted coastline $(<1 \%)$, and thus, those areas can be easily manually corrected if necessary.
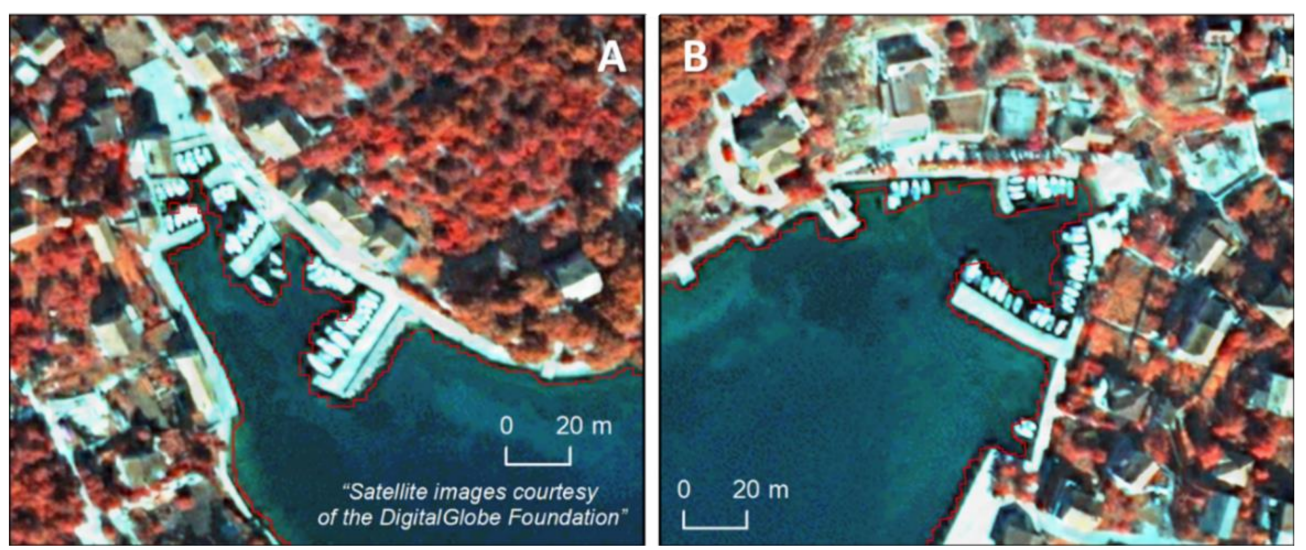

Figure 15. Overestimation of the extracted coastline caused by spectral disinformation affected by small fishing boats within Veli Iž (A) and Vela Rava (B) harbors.

The second limitation is related to the cloud cover, as CET performance is highly affected by artefacts in DSM or WV-2 MS, which are introduced by the presence of clouds in original high-resolution imagery. Those artefacts could limit the applicability of CET for the extraction of coastlines within the obstructed areas. Therefore, before the application of CET, users should ensure that their whole study area is free of any cloud cover. As our whole study area was without any cloud cover, such problems with the CET application have not been presented in the results.

\subsection{Future Upgrades of CET Tool}

In future research, we are planning to integrate data obtained by UAVs infrared thermography (IRT) and in situ sensors, measuring sea surface temperatures (SST), into the newly developed CET tool. Applications of IRT in measuring water temperature are diverse and have been employed in a wide variety of fluvial environments [80]. In the context of the coastline detection issue, [81] used Landsat 8 Operational Land Imager (OLI)/Thermal 
Infrared Sensor (TIRS) in extracting accurate demarcation line. However, we would focus on integrating very high-resolution thermal models. Namely, it is generally known that the amount of radiation emitted by an object increases with temperature. Compared to land, water surfaces on thermal-IR imagery in the daytime usually have very dark to medium tones, while in the nighttime, they have moderately light tones. If there is no significant water pollution, this can enable a clear localization of water surfaces [82].

Figure 16A-D shows land and sea surface temperature (LST and SST) models of different spatial resolutions (from $30 \mathrm{~m}$ up to $5 \mathrm{~cm}$ ) that can be potentially integrated into the CET tool. In Figure 16A, the surface temperature models of the Zadar County wider area with a spatial resolution of $30 \mathrm{~m}$ is shown. An isotherm of specific value was extracted from the SST model, and a clear demarcation line between the sea and the land can be seen (e.g., Pag, Dugi otok, Ugljan, Pašman). The optimal isotherm value, in this case, was determined by overlapping the derived LST with a high-resolution $(0.5 \mathrm{~m})$ digital orthophoto-DOP $(0.5 \mathrm{~m})$. However, in future research, the value of the isotherm can be determined based on several adequately distributed in situ measurements (thermometer) of sea surface temperature. Figure 16B-D shows surface temperature models with higher spatial resolutions ranging from $35 \mathrm{~cm}$ to $5 \mathrm{~cm}$. These models were made from thermal images (RPJEG format) that contained temperature information in each pixel and were collected by the UAV system Matrice 210 RTK V2 + Zenmuse XT2 at various flying altitudes. This thermal camera has a declared absolute accuracy of $10^{\circ} \mathrm{C}$ [83], but for observing land-sea temperature differences, relative accuracy is more important, which, in this case, is proved as satisfactory.

Figure 16C demonstrates a possible solution to the CET tool limitations previously listed in Section 4.2. Namely, the presence of artificial objects (e.g., fishing boats) close to the coast can lead to the overestimation of the extracted coastline (Figure 15). Although these values are not large, this drawback needs to be addressed. However, if very high $(<10 \mathrm{~cm})$ resolution surface temperature models are generated, this problem can be solved. This is best seen in the example of Sali Bay (Figure 16C). On this thermal model, the extracted isotherm perfectly delimits the boundary between the coast and the land. All fishing boats in Sali bay are not recognized as land, i.e., the boundary of the coastline is not oversized. Figure 16D shows the isotherm derived for the narrow coastal area of the Santiš gully from the most detailed $(5 \mathrm{~cm})$ surface temperature model generated. This wider coastal area is rich in coastal submerged freshwater springs that continuously flow through underground canals from the distant karst hinterland. These freshwater springs can also be felt physically in the sea due to the temperature, which is significantly lower than the surrounding sea. However, these environmental conditions did not negatively affect the derivation of a specific isotherm that would delaminate the land-sea surface.

Therefore, the CET can ultimately use multispectral, thermal, and RGB imagery of various spatial resolutions.

Furthermore, within future upgrades of the CET tool, we are planning to evaluate the influence of user-defined thresholds used for the extraction of preliminary coastlines from calculated spectral indices (NDWI and NDVI) on CET performance and accuracy. As these threshold values surely influence CET performance up to a certain point, we are planning to perform sensitivity analysis to evaluate the potential extent of such effects. 

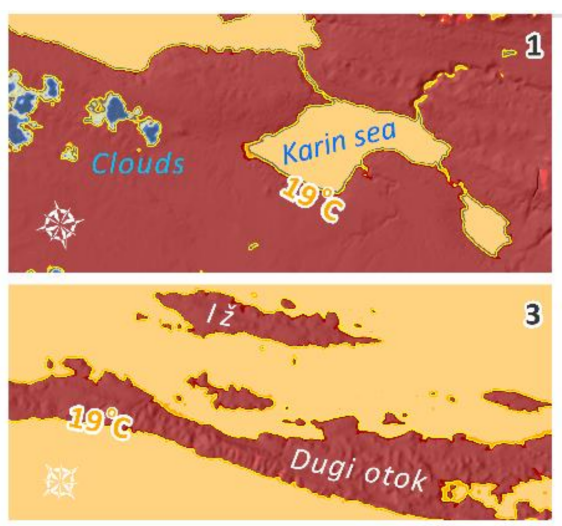

3
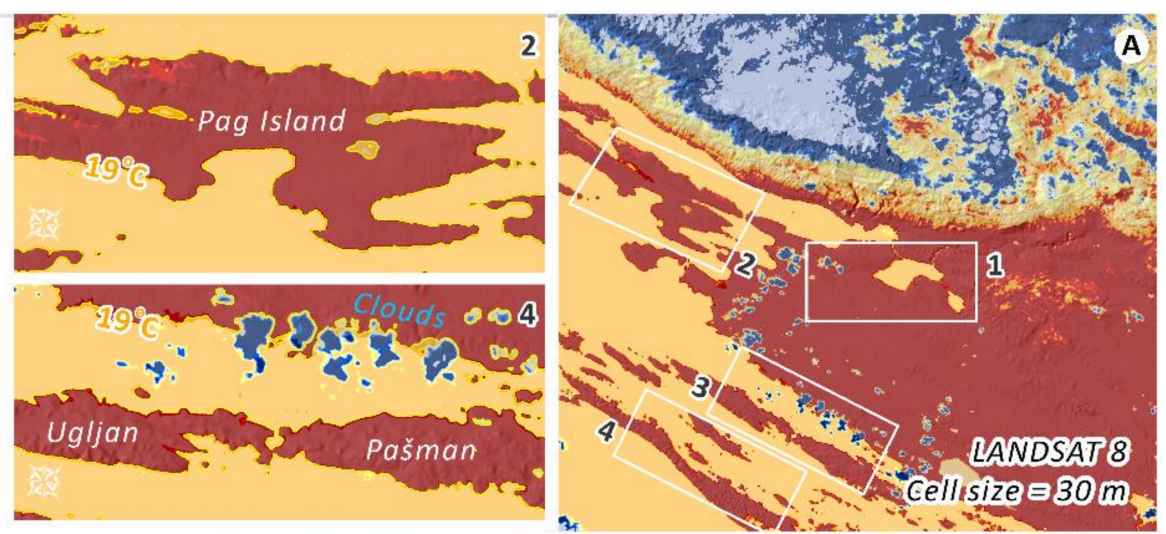

$x>$ a

B
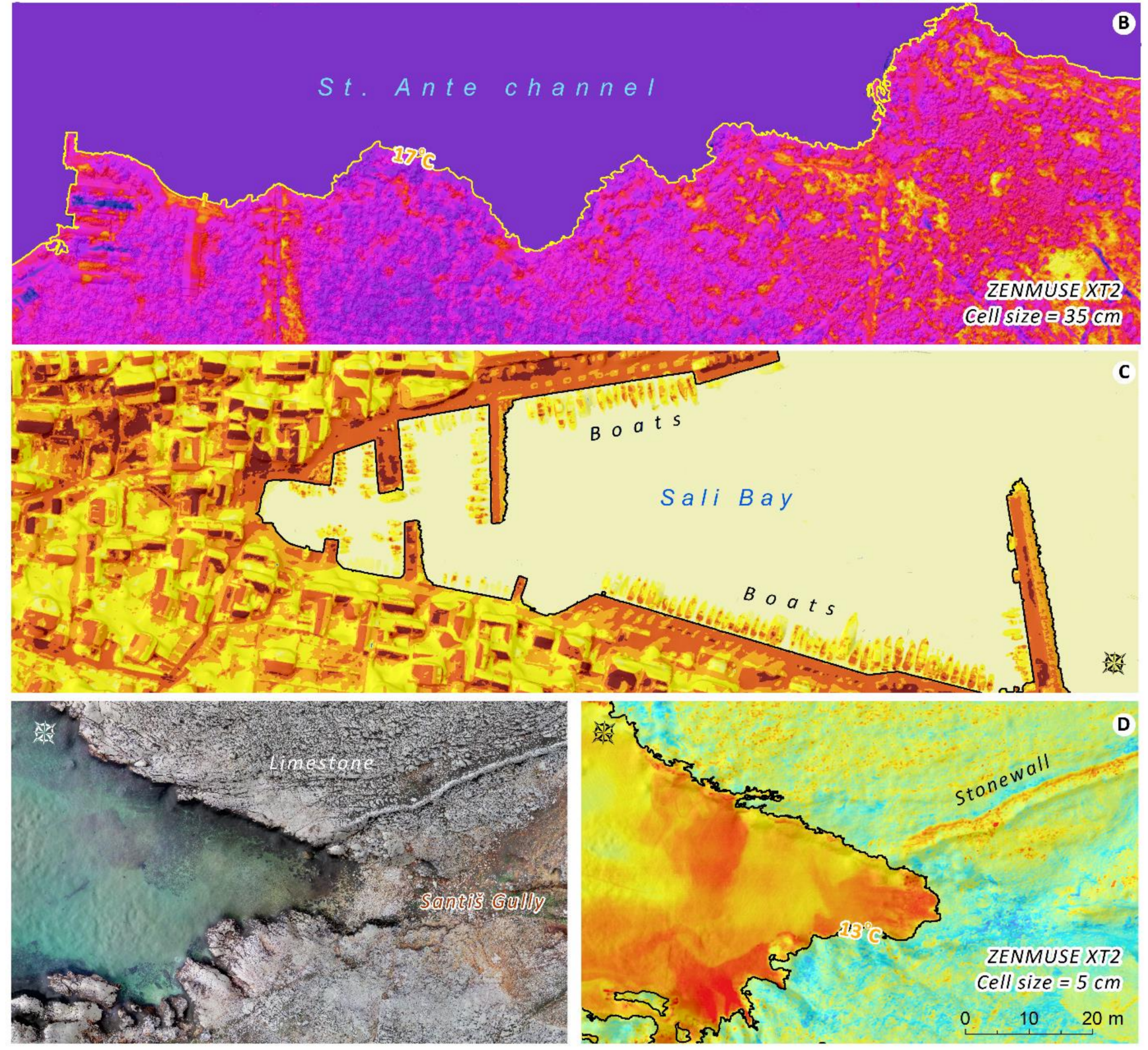

Figure 16. Land and sea surface temperatures generated for (A) the Zadar County wider area (spatial resolution $=30 \mathrm{M}$ ); (B) St. Ante channel (spatial resolution = $35 \mathrm{~cm}$ ); (C) Sali Bay (spatial resolution $=7 \mathrm{~cm}$ ); and (D) Santiš gully (spatial resolution $=5 \mathrm{~cm})$. 


\section{Conclusions}

In this study, the development and application of a new method for automated coastline extraction from VHR multispectral imagery and DSMs was conducted. The Coastal Extraction Tool (CET) was developed as a straightforward and simple-to-use tool that is applicable for accurate automated detection and extraction of coastlines. CET is recognized as a highly accurate tool that successfully overcomes spectral-induced errors (e.g., shadows or spectral reflections) that were present in coastlines extracted by other existing tested tools. Considering its accuracy and ease of use, we suggest that CET should be applied for automated coastline extraction in other large and indented coastal areas. Additionally, we suggest that it could be potentially applied for various purposes, e.g., the detection and mapping of multi-temporal changes in coastline position (1), detection of very small and fast-moving objects (e.g., fishing boats, aircrafts, etc.) (2), and mapping the coastal infrastructure and fish farms (3), etc.

In this study, we managed to determine the total number of islands, islets, rocks, and rocks awash within the Iž-Rava island group, significantly rising the total area and insular coastline length. As a result of the analysis, two small rocks (Sika and Garofulin) were detected within the study area, which due to their small size have not been mapped within earlier mapping efforts. Thus, this research managed to raise the official total number of islands, islets, rocks, and rocks awash in Croatia from 1246 to 1248. It is to be expected that the application of the same method in all Croatian coastal regions would further increase the number of Croatian rocks and rocks awash.

The application of the developed CET within the Iž-Rava island group has demonstrated that WV imagery has great potential for large-scale extraction of coastlines, from local to regional scale. Given the very high temporal and spatial resolution of the WV imagery, the application of CET on WV-derived models can significantly facilitate mapping efforts and provide effective management over very large coastal areas. Although the accuracy of such coastline extraction still lags behind "field-based" remote sensing methods (e.g., UAV photogrammetric survey), the accuracy achieved within the whole study area is very satisfactory. Therefore, within future research, $\mathrm{WV}$ imagery and developed CET should be used for detailed mapping of the whole Croatian coastline.

Supplementary Materials: The following are available online at https:/ /www.mdpi.com/article/10 .3390/app11209482/s1, Figure S1: Scheme of Coastal Extraction Tool (CET) created in ModelBuilder.

Author Contributions: Conceptualization, F.D., A.Š., and J.F.; Formal analysis, F.D.; Funding acquisition, A.Š. and J.F.; Investigation, F.D., A.Š., and I.M.; Methodology, F.D., A.Š., I.M., J.F., E.V., and L.P.; Project administration, F.D., A.Š., and J.F.; Resources, F.D. and A.Š.; Software, F.D., A.Š., and E.V.; Supervision, A.Š.; Validation, F.D., A.Š., I.M., J.F., and E.V.; Visualization, F.D., I.M., E.V., and L.P.; Writing—original draft, F.D., I.M., and L.P.; Writing—review and editing, F.D., I.M., J.F., and L.P. All authors have read and agreed to the published version of the manuscript.

Funding: This research was funded by the Italy-Croatia cross-border cooperation program 2014-2020 as part of the STREAM (Strategic development of flood management) project. This research was performed within the project UIP-2017-05-2694, which was financially supported by the Croatian Science Foundation. The authors would like to thank Croatian Science Foundation for providing necessary research funds.

Institutional Review Board Statement: Not applicable.

Informed Consent Statement: Not applicable.

Data Availability Statement: The data presented in this study are available on request from the corresponding author.

Acknowledgments: This publication was produced as part of the STREAM (Strategic development of flood management) project, funded by the Italy-Croatia cross-border cooperation program 20142020. This research was performed within the project UIP-2017-05-2694 financially supported by the Croatian Science Foundation. Authors would like to thank Croatian Science Foundation for providing necessary research funds. Authors would like to specially thank DigitalGlobe Foundation (Maxar 
Technologies), Hexagon Geospatial and SPH Engineering for providing required VHR Worldview satellite imagery and educational software licenses (Erdas Iamgine 2018 and UgCS). Tidal data provided by Hydrographic Institute of the Republic of Croatia (@ HHI). We thank Mirna Mazija, for acquisition of information and photographs of newly mapped rocks (Garofulin and Sika) within Iž-Rava island group.

Conflicts of Interest: The authors declare no conflict of interest.

\section{References}

1. International Hydrographic Organization (IHO). Hydrographic Dictionary; International Hydrographic Organisation: Monaco, 1974; p. 216.

2. Kuleli, T. Quantitative analysis of shoreline changes at the Mediterranean Coast in Turkey. Environ. Monit. Assess. 2009, 167, 387-397. [CrossRef] [PubMed]

3. Martinez, M.L.; Taramelli, A.; Silva, R. Resistance and Resilience: Facing the Multidimensional Challenges in Coastal Areas. J. Coast. Res. 2017, 77, 1-6. [CrossRef]

4. Kron, W. Coasts: The high-risk areas of the world. Nat. Hazards 2013, 66, 1363-1382. [CrossRef]

5. Hinkel, J.; Lincke, D.; Vafeidis, A.; Perrette, M.; Nicholls, R.; Tol, R.; Marzeion, B.; Fettweis, X.; Ionescu, C.; Levermann, A. Coastal flood damage and adaptation costs under 21st century sea-level rise. Proc. Natl. Acad. Sci. USA 2014, 111, 3292-3297. [CrossRef]

6. Simonovic, S.P.; Peck, A. Dynamic Resilience to Climate Change Caused Natural Disasters in Coastal Megacities Quantification Framework. Br. J. Environ. Clim. Chang. 2013, 3, 378-401. [CrossRef]

7. Neumann, B.; Vafeidis, A.T.; Zimmermann, J.; Nicholls, R.J. Future coastal population growth and exposure to sea-level rise and coastal flooding-a global assessment. PloS ONE 2015, 10, e0118571. [CrossRef]

8. United Nations. Factsheet: People and Oceans. In Proceedings of the Ocean Conference, New York, NY, USA, 5-6 June 2017.

9. Schwartz, M. Encyclopedia of Coastal Science; Springer Science \& Business Media: Dordrecht, The Netherlands, 2006.

10. Boak, E.H.; Turner, I. Shoreline Definition and Detection: A Review. J. Coast. Res. 2005, 214, 688-703. [CrossRef]

11. Li, R.; Liu, J.-K.; Felus, Y. Spatial Modeling and Analysis for Shoreline Change Detection and Coastal Erosion Monitoring. Mar. Geodesy 2001, 24, 1-12. [CrossRef]

12. Sunder, S.; Ramsankaran, R.; Ramakrishnan, B. Inter-comparison of remote sensing sensing-based shoreline mapping techniques at different coastal stretches of India. Environ. Monit. Assess. 2017, 189, 290. [CrossRef]

13. Roberts, J. What's the Difference Between Coastline and Shoreline? Available online: https://medium.com/@jenniferroberts050 60595/whats-the-difference-between-coastline-and-shoreline-982fcebf3ada (accessed on 15 January 2020).

14. Maglione, P.; Parente, C.; Vallario, A. Coastline extraction using high resolution WorldView-2 satellite imagery. Eur. J. Remote Sens. 2014, 47, 685-699. [CrossRef]

15. Dai, C.; Howat, I.M.; Larour, E.; Husby, E. Coastline extraction from repeat high resolution satellite imagery. Remote Sens. Environ. 2019, 229, 260-270. [CrossRef]

16. Zhu, Z.; Tang, Y.; Hu, J.; An, M. Coastline Extraction from High-Resolution Multispectral Images by Integrating Prior Edge Information With Active Contour Model. IEEE J. Sel. Top. Appl. Earth Obs. Remote Sens. 2019, 12, 4099-4109. [CrossRef]

17. Viaña-Borja, S.P.; Ortega-Sánchez, M. Automatic Methodology to Detect the Coastline from Landsat Images with a New Water Index Assessed on Three Different Spanish Mediterranean Deltas. Remote Sens. 2019, 11, 2186. [CrossRef]

18. Dolan, R.; Hayden, B.P.; May, P.; May, S. The reliability of shoreline change measurements from aerial photographs. Shore Beach 1980, 48, 22-29.

19. Di, K.; Ma, R.; Li, R. A Comparative Study of Shoreline Mapping Techniques. Res. Monogr. GIS 2004, 53-60. [CrossRef]

20. Shaw, J.B.; Wolinsky, M.A.; Paola, C.; Voller, V. An image-based method for shoreline mapping on complex coasts. Geophys. Res. Lett. 2008, 35. [CrossRef]

21. Mills, J.P.; Buckley, S.J.; Mitchell, H.L.; Clarke, P.J.; Edwards, S.J. A geomatics data integration technique for coastal change monitoring. Earth Surf. Process. Landforms 2005, 30, 651-664. [CrossRef]

22. Marfai, M.A.; Almohamad, H.; Dey, S.; Susanto, B.; King, L. Coastal dynamic and shoreline mapping: Multi-sources spatial data analysis in Semarang Indonesia. Environ. Monit. Assess. 2007, 142, 297-308. [CrossRef]

23. Moore, L.J. Shoreline mapping techniques. J. Coastal Res. 2000, 16, 111-124.

24. Alesheikh, A.A.; Ghorbanali, A.; Nouri, N. Coastline change detection using remote sensing. Int. J. Environ. Sci. Technol. 2007, 4, 61-66. [CrossRef]

25. Sanchez, A.J.; Lobo, F.J.; Azor, A.; Bárcenas, P.; Fernández-Salas, L.M.; del Río, V.D.; Peña, J.V.P. Human-driven coastline changes in the Adra River deltaic system, southeast Spain. Geomorphology 2010, 119, 9-22. [CrossRef]

26. Wang, X.; Liu, Y.; Ling, F.; Liu, Y.; Fang, F. Spatio-Temporal Change Detection of Ningbo Coastline Using Landsat Time-Series Images during 1976-2015. ISPRS Int. J. Geo-Inf. 2017, 6, 68. [CrossRef]

27. Ghosh, M.K.; Kumar, L.; Roy, C. Monitoring the coastline change of Hatiya Island in Bangladesh using remote sensing techniques. ISPRS J. Photogramm. Remote Sens. 2015, 101, 137-144. [CrossRef]

28. Nikolakopoulos, K.; Kyriou, A.; Koukouvelas, I.; Zygouri, V.; Apostolopoulos, D. Combination of Aerial, Satellite, and UAV Photogrammetry for Mapping the Diachronic Coastline Evolution: The Case of Lefkada Island. ISPRS Int. J. Geo-Inf. 2019, 8, 489. [CrossRef] 
29. Forgiarini, A.P.P.; De Figueiredo, S.A.; Calliari, L.J.; Goulart, E.S.; Marques, W.; Trombetta, T.B.; Oleinik, P.H.; Guimarães, R.C.; Arigony-Neto, J.; Salame, C.C. Quantifying the geomorphologic and urbanization influence on coastal retreat under sea level rise. Estuar. Coast. Shelf Sci. 2019, 230, 106437. [CrossRef]

30. Zhang, L.; Ouyang, Z. Focusing on rapid urbanization areas can control the rapid loss of migratory water bird habitats in China. Glob. Ecol. Conserv. 2019, 20, e00801. [CrossRef]

31. Ghoneim, E.; Mashaly, J.; Gamble, D.; Halls, J.; AbuBakr, M. Nile Delta exhibited a spatial reversal in the rates of shoreline retreat on the Rosetta promontory comparing pre- and post-beach protection. Geomorphology 2015, 228, 1-14. [CrossRef]

32. Lymburner, L.; Bunting, P.; Lucas, R.; Scarth, P.; Alam, I.; Phillips, C.; Ticehurst, C.; Held, A. Mapping the multi-decadal mangrove dynamics of the Australian coastline. Remote Sens. Environ. 2020, 238, 111185. [CrossRef]

33. Rangel-Buitrago, N.; Neal, W.J.; de Jonge, V.N. Risk assessment as tool for coastal erosion management. Ocean Coast. Manag. 2020, 186, 105099. [CrossRef]

34. Di, K.; Ma, R.; Wang, J.; Li, R. Coastal mapping and change detection using high-resolution IKONOS satellite imagery. In Proceedings of the 2003 Annual National Conference on Digital Government Research, Boston, MA, USA, 18-21 May 2003; pp. 1-4.

35. Sesli, F.A.; Karsli, F.; Colkesen, I.; Akyol, N. Monitoring the changing position of coastlines using aerial and satellite image data: An example from the eastern coast of Trabzon, Turkey. Environ. Monit. Assess. 2008, 153, 391-403. [CrossRef]

36. Li, X.; Damen, M.C. Coastline change detection with satellite remote sensing for environmental management of the Pearl River Estuary, China. J. Mar. Syst. 2010, 82, S54-S61. [CrossRef]

37. Dewi, R.S.; Bijker, W.; Stein, A.; Marfai, M.A. Fuzzy Classification for Shoreline Change Monitoring in a Part of the Northern Coastal Area of Java, Indonesia. Remote Sens. 2016, 8, 190. [CrossRef]

38. Saleem, A.; Awange, J. Coastline shift analysis in data deficient regions: Exploiting the high spatio-temporal resolution Sentinel-2 products. Catena 2019, 179, 6-19. [CrossRef]

39. Gens, R. Remote sensing of coastlines: Detection, extraction and monitoring. Int. J. Remote Sens. 2010, 31, 1819-1836. [CrossRef]

40. Sammler, K.G. The rising politics of sea level: Demarcating territory in a vertically relative world. Territ. Politics Gov. 2020, 8, 604-620. [CrossRef]

41. Stoa, R. The Coastline Paradox. Rutgers Univ. Law Rev. 2020, 72, 50. [CrossRef]

42. Morton, R.A. Accurate shoreline mapping: Past, present, and future. In Coastal Sediments; American Society of Civil Engineers: New York, NY, USA, 1991; pp. 997-1010.

43. Liu, Y.; Wang, X.; Ling, F.; Xu, S.; Wang, C. Analysis of Coastline Extraction from Landsat-8 OLI Imagery. Water 2017, 9, 816. [CrossRef]

44. Niya, A.K.; Alesheikh, A.A.; Soltanpor, M.; Kheirkhahzarkesh, M.M. Shoreline change mapping using remote sensing and GIS. Inter. J. Remote Sens. Appl. 2013, 3, 102-107.

45. Ding, Y.; Yang, X.; Jin, H.; Wang, Z.; Liu, Y.; Liu, B.; Zhang, J.; Liu, X.; Gao, K.; Meng, D. Monitoring Coastline Changes of the Malay Islands Based on Google Earth Engine and Dense Time-Series Remote Sensing Images. Remote Sens. 2021, $13,3842$. [CrossRef]

46. Paravolidakis, V.; Ragia, L.; Moirogiorgou, K.; Zervakis, M.E. Automatic Coastline Extraction Using Edge Detection and Optimization Procedures. Geosciences 2018, 8, 407. [CrossRef]

47. Guariglia, A.; Buonamassa, A.; Losurdo, A.; Saladino, R.; Trivigno, M.L.; Zaccagnino, A.; Colangelo, A. A multisource approach for coastline mapping and identification of shoreline changes. Ann. Geophys. 2009, 49, 295. [CrossRef]

48. Guo, Q.; Pu, R.; Zhang, B.; Gao, L. A comparative study of coastline changes at Tampa Bay and Xiangshan Harbor during the last 30 years. In Proceedings of the 2016 IEEE International Geoscience and Remote Sensing Symposium (IGARSS), Beijing, China, 10-15 July 2016; pp. 5185-5188. [CrossRef]

49. Zanutta, A.; Lambertini, A.; Vittuari, L. UAV Photogrammetry and Ground Surveys as a Mapping Tool for Quickly Monitoring Shoreline and Beach Changes. J. Mar. Sci. Eng. 2020, 8, 52. [CrossRef]

50. Duplančić Leder, T.; Ujević, T.; Čala, M. Coastline lenghts and areas of islands in the croatian part of the Adriatic Sea determined from the topographic maps at the scale of 1: 25,000. Geoadria 2004, 9, 5-32.

51. State Geodetic Administration of the Republic of Croatia. Data Catalog (Version 1.11). 2020. Available online: https: / / dgu.gov.hr/UserDocsImages//dokumenti/Pristup\%20informacijama/Zakoni\%20i\%20ostali\%20propisi/Ostalo//Katalog_ podataka_DGU_2018_v11.pdf (accessed on 14 November 2020).

52. Faričić, J. Geografija Sjevernodalmatinskih Otoka [Geography of North Dalmatian islands]; Školska Knjiga dd, Zadar Sveučilište u Zadru: Zagreb, Croatia, 2012.

53. Pikelj, K.; Juračić, M. Eastern Adriatic Coast (EAC): Geomorphology and coastal vulnerability of a karstic coast. J. Coastal Res. 2013, 29, 944-957. [CrossRef]

54. Digital Globe Foundation (DGF). Imagery Grant Application Process. 2019. Available online: http:/ / www.digitalglobefoundation. org (accessed on 18 September 2019).

55. Roa-Melgarejo, O.; Ariza, A.; Ramírez, H.M.; León-Rincón, H. Comparison of ATCOR Atmospheric and ELM Linear Empirical Correction Models Applied to WorldView-2 Images. Tecciencia 2018, 13, $29-38$.

56. Vermeulen, D.; van Niekerk, A. Evaluation of a WorldView-2 image for soil salinity monitoring in a moderately affected irrigated area. J. Appl. Remote Sens. 2016, 10, 1-32. [CrossRef] 
57. Madonsela, S.; Cho, M.A.; Mathieu, R.; Mutanga, O.; Ramoelo, A.; Kaszta, Ż.; Van De Kerchove, R.; Wolff, E. Multi-phenology WorldView-2 imagery improves remote sensing of savannah tree species. Int. J. Appl. Earth Obs. Geoinf. 2017, 58, 65-73. [CrossRef]

58. Aguilar, M.A.; Novelli, A.; Nemamoui, A.; Aguilar, F.J.; Lorca, A.G.; González-Yebra, Ó. Optimizing Multiresolution Segmentation for Extracting Plastic Greenhouses from WorldView-3 Imagery. In Proceedings of the Handbook of Deep Learning Applications; Gabler: Vilamoura, Portugal, 2018; pp. 31-40.

59. Li, H.; Jing, L.; Tang, Y. Assessment of Pansharpening Methods Applied to WorldView-2 Imagery Fusion. Sensors 2017, 17, 89. [CrossRef]

60. Li, X.; He, M.; Zhang, L. Hyperspherical color transform based pansharpening method for WorldView-2 satellite images. In Proceedings of the 2013 IEEE 8th Conference on Industrial Electronics and Applications (ICIEA), Melbourne, Australia, 19-21 June 2013; pp. 520-523.

61. Cheng, P.; Chaapel, C. Pan-sharpening and Geometric Correction: WorldView-2 Satellite. GeoInformatics 2010, 13, 30.

62. Aguilar, M.A.; Saldaña, M.D.M.; Aguilar, F.J. Assessing geometric accuracy of the orthorectification process from GeoEye-1 and WorldView-2 panchromatic images. Int. J. Appl. Earth Obs. Geoinf. 2013, 21, 427-435. [CrossRef]

63. ESRI. Overview of Georeferencing. Available online: https://pro.arcgis.com/en/pro-app/help/data/imagery/overview-ofgeoreferencing.htm (accessed on 23 May 2021).

64. Jain, K.; Ravibabu, M.V.; Shafi, J.A.; Singh, S.P. Using rational polynomial coefficients (RPC) to generate digital elevation models-A comparative study. Appl. GIS 2009, 5, 1-11.

65. Goldbergs, G.; Maier, S.W.; Levick, S.R.; Edwards, A. Limitations of high resolution satellite stereo imagery for estimating canopy height in Australian tropical savannas. Int. J. Appl. Earth Obs. Geoinf. 2019, 75, 83-95. [CrossRef]

66. Domazetović, F.; Šiljeg, A.; Marić, I.; Jurišić, M. Assessing the Vertical Accuracy of Worldview-3 Stereo-extracted Digital Surface Model over Olive Groves. In Proceedings of the 6th International Conference on Geographical Information Systems Theory, Applications and Management, Prague, Czech Republic, 7-9 May 2020; pp. 246-253.

67. DJI. MATRICE 600 PROSpecs. 2020. Available online: https://www.dji.com/hr/matrice600-pro/info\#specs (accessed on 15 November 2020).

68. MicaSense. RedEdge MX-The Sensor That Doesn't Compromise. 2020. Available online: https://micasense.com/rededge-mx/ (accessed on 15 November 2020).

69. James, M.R.; Chandler, J.H.; Eltner, A.; Fraser, C.; Miller, P.E.; Mills, J.P.; Lane, S.N. Guidelines on the use of structure-from-motion photogrammetry in geomorphic research. Ear. Sur. Proc. Land. 2019, 44, 2081-2084. [CrossRef]

70. Hexagon. Extract Coastline from WorldView-2 \& -3 Satellite Imagery. 2020. Available online: https://community hexagongeospatial.com/t5/Spatial-Modeler-Tutorials/Extract-Coastline-from-WorldView-2-amp-3-satellite-imagery/ta-p/ 27448 (accessed on 5 March 2020).

71. Himmelstoss, E.A.; Henderson, R.E.; Kratzmann, M.G.; Farris, A.S. Digital Shoreline Analysis System (DSAS) Version 5.0 User Guide; Open-File Report 2018-1179; USGS: Reston, VA, USA, 2018.

72. Tsokos, A.; Kotsi, E.; Petrakis, S.; Vassilakis, E. Combining series of multi-source high spatial resolution remote sensing datasets for the detection of shoreline displacement rates and the effectiveness of coastal zone protection measures. J. Coast. Conserv. 2018, 22, 431-441. [CrossRef]

73. Heiselberg, H. Aircraft and Ship Velocity Determination in Sentinel-2 Multispectral Images. Sensors 2019, 19, 2873. [CrossRef] [PubMed]

74. Nagarajan, S.; Khamaru, S.; De Witt, P. UAS based 3D shoreline change detection of Jupiter Inlet Lighthouse ONA after Hurricane Irma. Int. J. Remote Sens. 2019, 40, 9140-9158. [CrossRef]

75. Corbane, C.; Najman, L.; Pecoul, E.; Demagistri, L.; Petit, M. A complete processing chain for ship detection using optical satellite imagery. Int. J. Remote Sens. 2010, 31, 5837-5854. [CrossRef]

76. Gianinetto, M.; Aiello, M.; Marchesi, A.; Topputo, F.; Massari, M.; Lombardi, R.; Banda, F.; Tebaldini, S. OBIA ship detection with multispectral and SAR images: A simulation for Copernicus security applications. In Proceedings of the 2016 IEEE International Geoscience and Remote Sensing Symposium (IGARSS), Beijing, China, 10-15 July 2016; pp. 1229-1232.

77. Kanjir, U. Detecting migrant vessels in the Mediterranean Sea: Using Sentinel-2 images to aid humanitarian actions. Acta Astronaut. 2019, 155, 45-50. [CrossRef]

78. Kurekin, A.A.; Loveday, B.R.; Clements, O.; Quartly, G.D.; Miller, P.I.; Wiafe, G.; Agyekum, K.A. Operational Monitoring of Illegal Fishing in Ghana through Exploitation of Satellite Earth Observation and AIS Data. Remote Sens. 2019, 11, 293. [CrossRef]

79. Maxar. Worldview-2. Datasheet. 2020. Available online: https://www.maxar.com/constellation (accessed on 12 November 2020).

80. Handcock, R.N.; Torgersen, C.E.; Cherkauer, K.A.; Gillespie, A.R.; Tockner, K.; Faux, R.N.; Tan, J. Thermal Infrared Remote Sensing of Water Temperature in Riverine Landscapes. Fluv. Remote Sens. Sci. Manag. 2012, 1, 85-113. [CrossRef]

81. Ghorai, D.; Mahapatra, M. Extracting Shoreline from Satellite Imagery for GIS Analysis. Remote Sens. Ear. Syst. Sci. 2020, 3, 1-10. [CrossRef]

82. Lega, M.; Napoli, R.M.A. Aerial infrared thermography in the surface waters contamination monitoring. Desalination Water Treat. 2010, 23, 141-151. [CrossRef]

83. DJI. Zenmuse XT2-User Manual 1.0. 2018. Available online: https://www.dji.com/hr/downloads/products / zenmuse-xt2 (accessed on 19 January 2021). 